\title{
Evolutionary agglomeration theory: increasing returns, diminishing returns, and the industry life cycle
}

\author{
Antony Potter ${ }^{*, \ddagger}$ and H. Doug Watts ${ }^{\dagger}$
}

*Queen's University Management School, Queen's University Belfast, Belfast, Northern Ireland, BT7 1NN, UK.

${ }^{\dagger}$ Department of Geography, University of Sheffield, Sheffield, S10 2TN, UK.

ॠCorresponding author: Antony Potter, Queen's University Management School, Queen’s University Belfast, Belfast, Northern Ireland, BT7 1NN, UK. email<a.potter@qub.ac.uk>

\begin{abstract}
According to Marshall's agglomeration theory, Krugman's New Economic Geography models, and Porter's cluster policies, firms should receive increasing returns from a trinity of agglomeration economies: a local pool of skilled labour, local supplier linkages, and local knowledge spillovers. Recent evolutionary theories suggest that whether agglomeration economies generate increasing returns or diminishing returns depends on time, and especially the evolution of the industry life cycle. At the start of the 21st century, we re-examine Marshall's trinity of agglomeration economies in the city-region where he discovered them. The econometric results from our multivariate regression models are the polar opposite of Marshall's. During the later stages of the industry life cycle, Marshall's agglomeration economies decrease the economic performance of firms and create widespread diminishing returns for the economic development of the city-region, which has evolved to become one of the poorest cityregions in Europe.
\end{abstract}

Keywords: Marshall, cluster, agglomeration, industrial district, external economies, development, city-region, network, supply chain, industry life cycle, evolution, Darwin

JEL classifications: B52, O18, O33, R11, R12

Date submitted: 7 November 2009 Date accepted: 14 January 2010

\section{Introduction}

A industrial district which is dependent chiefly on one industry is liable to 'extreme depression', in case of a falling-off in the demand for its produce, or of a failure in the supply of the raw material which it uses.

(Alfred Marshall, 1890, 273)

Over 100 years ago, the classical economist Alfred Marshall (1890) warned explicitly that the agglomeration of firms in close geographical proximity could have a substantial negative impact on the development of firms, cities, and regions. In an overlooked, and rarely cited, quote from his famous text The Principles of Economics, Marshall (1890, 273) identified that an agglomeration dependent on one industry for its economic 
development is likely to suffer from diminishing returns, and even 'extreme depressions' (Martin, 2006). However, Marshall (1890) also argued that by agglomerating in close geographical proximity, firms could receive increasing returns from a trinity of agglomeration economies: a local pool of skilled labour, local supplier linkages, and local knowledge spillovers. Somewhat paradoxically, many economic geographers continue to use Marshall's (1890) agglomeration theory to argue that agglomeration creates greater economic performance, increasing returns, and economic development, most notably within Krugman's (1991a) New Economic Geography (NEG) models and Porter's (1990) cluster policies.

Recently, there has been a growing trend of explaining the development of agglomerations using evolutionary models, theories, concepts, perspectives, metaphors, and methodologies (Boschma and Frenken, 2006; Boschma and Martin, 2007; Frenken and Boschma, 2007; Frenken, 2007). Moreover, an increasing number of economic geographers have proposed that whether agglomeration generates increasing returns or diminishing returns is dependent on time, and especially the evolution of the industry life cycle (Boschma and Lambooy, 1999; Maskell and Malmberg, 2007; Essletzbichler and Rigby, 2007). Similarly, many economists have also begun to incorporate industry life cycle theories into their economic models to explain the development of cities and regions (Brezis and Krugman, 1997; Duranton and Puga, 2001). In parallel with this trend, a number of academics in management science, who focus primarily on industry life cycles, have also begun to incorporate agglomeration theories into their research (Klepper, 2007). In addition, empirical research has found that the life cycles of industries and agglomerations are indeed closely interrelated (Audretsch and Feldman, 1996; Rigby and Essletzbichler, 1997; Boschma and Wenting, 2007).

Despite this theoretical convergence, the literatures on the evolution of industries and that concerning the evolution of agglomerations have remained largely separate from one another, with only a few notable exceptions (Martin, 2006). Within this article, we attempt to bridge this divide by arguing that industry life-cycle theories, when used in conjunction with agglomeration theories, can help to explain the development of cities and regions over time and geographical space in a manner that represents an Evolutionary Agglomeration Theory (EAT). To examine this Evolutionary Agglomeration Theory ( $E A T)$, we return to the same city-region wherein Marshall (1890) discovered his trinity of agglomeration economies, which, somewhat ironically, has evolved to become one of the poorest regions in Europe (namely, the city of Sheffield and the surrounding South Yorkshire region in the UK) (European Commission, 2005). Using multivariate econometric techniques, we demonstrate that during the later stages of the industry life cycle, Marshall's (1890) agglomeration economies decrease the economic performance of plants within the manufacturing sector as a whole, and the plants within the metals industry in particular, which ultimately generates widespread diminishing returns for the development of the city and the surrounding region. Specifically, our empirical results indicate that a local pool of skilled labour generates higher labour costs and higher total costs, local supplier linkages cause cost growth and lower profit margins, and local knowledge spillovers generate lower sales turnover and lower profit growth.

The remainder of this article is structured as follows. In Section 2, we demonstrate how evolutionary changes in the industry life cycle can explain the evolution of agglomerations over time and geographical space. Following this, Section 3 outlines the research hypotheses that will be examined. Section 4 discusses the history of Marshall's (1890) agglomeration theory, before detailing the methodological approach used in the 
study. Section 5 outlines the empirical results from a series of multivariate regression models (for the manufacturing sector as a whole) and from the bivariate regression analysis of the metals industry. Following this, Section 6 discusses the theoretical implications of our findings. Finally, conclusions and future research directions are highlighted in Section 7.

\section{Theoretical framework: evolutionary agglomeration theory}

Alfred Marshall (1890) was the first economist to explore how firms and industries evolve, highlighting how different industries are characterized by increasing returns or diminishing returns, and how these change over time ${ }^{1}$ (Schumpeter, 1941; Thomas, 1991; Dosi and Nelson, 1994; Raffaelli et al., 2006). In order to explain the evolution of industries, Marshall (1898) frequently used the metaphor of industries as forests with young, mature, and dying trees that follow an evolutionary life cycle. Building upon this theoretical perspective, many scholars argue that industries evolve according to a similar pattern, known as the industry life cycle (which is also referred to as the "product life cycle') (Vernon, 1966; Klepper and Grady, 1990; Klepper, 1996; Agarwal and Gort, 2002; Agarwal and Audretsch, 2001). According to this theory, the archetypal evolution of an industry follows a logistic curve, which consists of an embryonic stage, followed by a growth stage, which is then succeeded by a mature stage, and an eventual decline stage (Segerstrom et al., 1990; Jovanovic and MacDonald, 1994; Klepper, 1997; Greenstein and Wade, 1998). In particular, empirical research has found that the evolution of many industries follow this logistic curve, which is remarkably similar to the development path of many cities and regions that contain an agglomeration of firms within one industry (Norton and Rees, 1979; Booth, 1986; Audretsch and Feldman, 1996; Press, 2006). Whilst some industries and regions have their own idiosyncrasies that can alter the nature of their development, many do evolve according to the industry life cycle (Storper, 1985).

Building upon Marshall's (1890) theoretical perspective, we outline an Evolutionary Agglomeration Theory (EAT) that explains how the industry life cycle influences the evolution of an agglomeration over time and across geographical space. Specifically, we argue that Marshall's (1890) agglomeration economies create greater economic performance and increasing returns at the start of the industry life cycle, but declining economic performance and diminishing returns during the later stages of the industry life cycle. To explain this rationale, we have developed a theoretical model called the Agglomeration Life Cycle (ALC) Model that illustrates how the incentives to agglomerate and disperse evolve over time, and how the industry life cycle changes the relationship between Marshall's (1890) agglomeration economies and economic performance (Figure 1). This Evolutionary Agglomeration Theory (EAT) is based primarily upon recent theoretical developments within Evolutionary Economic Geography (EEG) (Boschma and Lambooy, 1999; Boschma and Frenken, 2006;

1 In addition, Alfred Marshall (1898) is credited with being one of the founders of evolutionary economics (Veblen, 1898; Nelson and Winter, 1982; Hodgson, 1993) due to his declaration that "The Mecca of the economist is economic biology rather than economic dynamics. But biological conceptions are more complex than those of mechanics... And therefore in the later stages of economics, when we are approaching nearly to the conditions of life, biological analogies are to be preferred to mechanical, other things being equal" (Marshall, 1898, 43-47). 


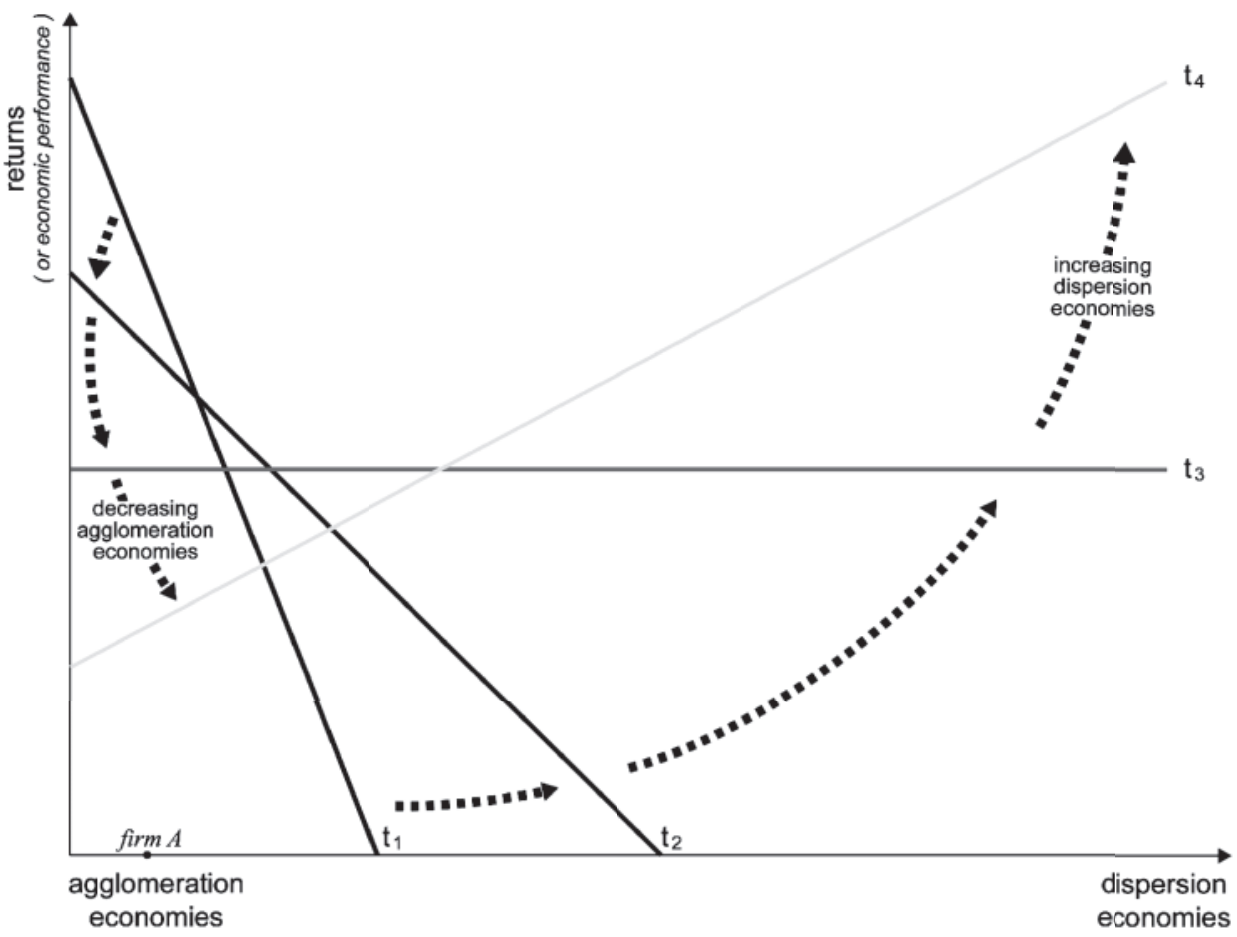

Key. The Agglomeration Life Cycle (ALC) Model

\begin{tabular}{ccccc}
\hline time & $\begin{array}{c}\text { industry } \\
\text { life cycle }\end{array}$ & $\begin{array}{c}\text { agglomeration } \\
\text { economies }\end{array}$ & $\begin{array}{c}\text { dispersion } \\
\text { economies }\end{array}$ & $\begin{array}{c}\text { agglomeration } \\
\text { life cycle }\end{array}$ \\
\hline $\mathbf{t}_{\mathbf{1}}$ & embryonic stage & increasing returns & diminishing returns & embryonic agglomeration \\
$\mathbf{t}_{\mathbf{2}}$ & growth stage & increasing returns & diminishing returns & growth agglomeration \\
$\mathbf{t}_{\mathbf{3}}$ & mature stage & constant returns & constant returns & mature agglomeration \\
$\mathbf{t}_{\mathbf{4}}$ & decline stage & diminishing returns & increasing returns & decline agglomeration \\
\hline
\end{tabular}

Source: present authors

Figure 1. The Agglomeration Life Cycle (ALC) Model.

Boschma and Martin, 2007; Frenken, 2007), research into the evolution of the industry life cycle (Vernon, 1966; Abernathy and Utterback, 1978; Klepper, 1996), and Marshall's (1890) original theories of agglomeration, increasing returns, and diminishing returns. The theory has also been informed by concepts from regional science and urban economics (Von Thünen, 1826; Alonso, 1964; Hägerstrand, 1967), New Economic Geography (Krugman, 1991a; Brezis and Krugman, 1997; Fujita et al., 1999), and detailed empirical research and case studies into the histories and evolution of industries, agglomerations, networks, and supply chains (Womack et al., 1990; Grabher, 1993; Saxenian, 1994; Henderson et al., 2002; Phelps and Ozawa, 2003; Glaeser, 2005; Klepper, 2007; Wal and Boschma, 2010; Menzel and Fornahl, 2009; Neffke et al., 2010). In addition, like many of the studies of Evolutionary Economic 
Geography (EEG) cited above, we also draw insights from theories within biological science, evolutionary biology and biogeography (Darwin, 1859; Ehrlich and Raven, 1964; Axelrod and Hamilton, 1981; Holland, 1992), evolutionary economics and economic biology (Veblen, 1898; Schumpeter, 1942; Nelson and Winter, 1982; Hayek, 1945). In drawing metaphors from other disciplines it must be stressed these are just metaphors which are used here to highlight the close connection between the literature on evolutionary biology and Evolutionary Economic Geography (EEG) (Barnes, 1996). Although such metaphors assist in the development of our arguments there are the limitations of drawing analogies between different disciplines as has been highlighted by Barnes (1996).

Figure 1 outlines the details of the Agglomeration Life Cycle (ALC) Model, within which agglomeration economies (i.e. centripetal forces) and dispersion economies (i.e. centrifugal forces) are represented along the $x$-axis, whilst the returns (or economic performance) that firms experience are illustrated along the $y$-axis. The four lines within the Agglomeration Life Cycle (ALC) Model illustrate the relationship between agglomeration economies, dispersion economies and returns (or economic performance) during the four different stages of the industry life cycle (i.e. $t_{1}, t_{2}, t_{3}$ and $t_{4}$ ). Each of the four lines represent the returns (or economic performance) a firm will experience from different combinations of agglomeration economies and dispersion economies at that time period within the industry life cycle. For example, consider a typical firm within an industrial agglomeration, as represented by 'firm $A$ ' along the x-axis of Figure 1. If this firm decides to increase the extent of agglomeration economies it experiences, by either employing a greater proportion of its employees from a local pool of skilled labour, by sourcing a larger share of materials from local suppliers, or by increasing its reliance upon local knowledge spillovers, then the firm will shift to the left along the $x$-axis. Such an increase in agglomeration economies will cause the firm to experience increasing returns and greater economic performance during the embryonic and growth stages of the life cycle (i.e. at $t_{1}$ and $t_{2}$ ), constant returns during the mature stage (i.e. at $t_{3}$ ), but diminishing returns and declining economic performance during the decline stage of the life cycle (i.e. at $t_{4}$ ). In order to explain this evolutionary change, we now explore the different stages of the Agglomeration Life Cycle (ALC) Model in greater depth.

\subsection{Embryonic agglomeration}

The beginning of the industry life cycle starts with a mutation process (Schumpeter, 1942). This occurs when a small group of inquisitive individuals, entrepreneurs, scientists, technologists, and R\&D-intensive firms begin to develop new knowledge, routines, technology, radical innovations, products and services that do not exist within the marketplace (Schumpeter, 1942; Audretsch and Feldman, 1996; Klepper, 1997). Importantly, these firms will experience a first-mover advantage by being the first firms to enter the embryonic industry, and will become the common ancestors from which different descendents and species of firm will evolve within the industry (i.e. as illustrated by Darwin's (1859) famous tree of life theory) (Lieberman and Montgomery, 1988). During this creative period, the embryonic industry is characterized by high rates of start-up (i.e. firm birth), spin-off (i.e. heredity), and firm entry (i.e. migration), from which emerges one of the most important drivers of evolution: competition (i.e. biological intraspecific competition and interspecific competition) (Klepper and Miller, 1995; Ridley, 2004; Campbell et al., 2008). 
Geography is crucial during the embryonic stage because a number of evolutionary processes occur which encourage firms to agglomerate in close geographical proximity (Boschma and Frenken, 2006). First, a small number of firms begin to agglomerate in close geographical proximity to the founders, entrepreneurs, and star scientists who create start-up firms within the industry, a process known as the founder effect (Zucker and Darby, 2006). Second, owing to heredity and the spin-off process, the firms that spin off from their parent firm will naturally inherit some of the knowledge and routines that enabled their parent firm to become successful, and because spin-off firms often colocate near to their parent firm, especially through kin selection, this also fosters agglomeration (i.e. which is similar to the biological theory of vertical gene transfer whereby genes are passed down from parents to their offspring over time) (Futuyma, 1998; Boschma and Frenken, 2006; Boschma and Wenting, 2007; Campbell et al., 2008). Third, the tacit knowledge created within the new industry remains inherently difficult to transfer between firms except when they agglomerate are in close proximity, which, in many ways, is analogous to the biological theory of horizontal gene transfer that occurs when genes are transferred between different organisms and species (Hayek, 1945; Von Hippel, 1998; Ricklefs and Miller, 2000; Wal and Boschma, 2010). Fourth, although the firms within the embryonic agglomeration maintain global linkages and knowledge of different technologies throughout the life cycle, over time many also specialize in particular stages of production (i.e. the evolution of generalist and specialist species) (Ridley, 2004). This increases the agglomeration's biodiversity and results in the development of a local supply chain and a local production network, which is analogous to the interdependence found within a biological food chain or food web (Campbell et al., 2008). Fifth, during this period many firms choose to remain within the agglomeration in order to maintain their local social ties, network centrality, network connectivity, and supply chain linkages that are characterized by a high degree of embeddedness, relational trust, altruism, reciprocity and cognitive proximity (i.e. biological co-operation) (Axelrod and Hamilton, 1981; Granovetter, 1985; Pyke et al., 1990; Gertler, 1995). Sixth, through the imitation process, competing firms begin to imitate, mimic, and reverse engineer the new products and routines developed by the first movers within the industry, and because imitation is facilitated by geographical proximity, this encourages firms to agglomerate as well (i.e. biological mimicry) (Mansfield, 1961; Lippman and Rumelt, 1982; Zander and Kogut, 1995; Ridley, 2004). Finally, just like random genetic variation, it is also possible that industries and agglomerations evolve from a random process in which chance events become magnified and sustained through positive feedback loops, cumulative causation, and selfreinforcing effects (Arthur, 1994; Ricklefs and Miller, 2000).

Eventually, as a result of spontaneous order, an embryonic agglomeration begins to develop within a particular locality that resembles a local ecosystem where firms experience greater economic performance and increasing returns by agglomerating in close geographical proximity (Audretsch and Feldman, 1996). For instance, attracted by the greater returns within the agglomeration, and especially by the first-mover advantage (Lieberman and Montgomery, 1988), a growing number of firms begin to migrate and relocate to the agglomeration (i.e. herd behaviour) (Banerjee, 1992). Consequently, during the embryonic stage of the industry life cycle, firms experience increasing returns from agglomeration economies, but diminishing returns from dispersion economies (i.e. during $t_{1}$ in Figure 1). 


\subsection{Growth agglomeration}

After a long process of learning by doing and incremental innovations, many of the technological problems that prevented the industry from growing are solved, which enables firms to ramp up the production of new products (Arrow, 1962; Jovanovic and Lach, 1989). As success breeds success, the embryonic stage evolves into the growth stage of the industry life cycle, which is characterized by a rapid increase in the rates of firm entry, start-up, spin-off and survival combined with a continued low rate of firm exit from the industry (Dunne et al., 1988; Klepper and Miller, 1995). For example, empirical research has found that during this period in the industry life cycle there can be increases of $30 \%$ or more in the number of firms within the industry (i.e. biological population growth) (Klepper, 1996; Agarwal and Gort, 2002). Within this environment, firms continue to compete by pursuing a product differentiation strategy that emphasizes the use of $R \& D$ to create radical product innovations, which also helps to increase the biodiversity of the agglomeration's ecosystem (i.e. niche differentiation) (Utterback and Abernathy, 1975; Audretsch and Feldman, 1996). In addition, it is during the early stages of the industry life cycle that venture capitalists, institutional investors, trade associations, supportive institutions, universities, and professional gatherings become involved with the industry, often choosing to collocate in close proximity to the firms within the agglomeration to ensure network centrality and connectivity (Boschma and Frenken, 2009; Grabher, 2009).

Once again, there is a geographical dimension as both new and existing firms continue to agglomerate in close geographical proximity, thus creating a large growth agglomeration that has a positive lock-in effect for regional development (Pyke et al., 1990; Porter, 1990; Saxenian, 1994). For example, through the replication process, as successful firms grow they reinvest their profits into developing their own R\&D capabilities, increasing their workforce, expanding their existing production capacity, building local supply chains, and establishing local subsidiary plants (e.g. clone plants) (i.e. a process that resembles asexual reproduction) (Ricklefs and Miller, 2000; Winter and Szulanski, 2001). This not only contributes to the growth of the agglomeration but also fosters the local replication and diffusion of successful routines (Hägerstrand, 1967; Frenken and Boschma, 2007). Importantly, during the early stages of the industry life cycle, an agglomeration evolves that generates increasing returns at the local scale, especially from Marshall's (1890) trinity of agglomeration economies: a local pool of skilled labour, local supplier linkages, and local knowledge spillovers. First, the creation of a local pool of skilled labour facilitates specialization, fosters the replication of successful routines through labour mobility, and raises the overall fitness of the agglomeration's routines (i.e. which is analogous to the biological theory of gene flow, whereby new routines flow between different local firms through labour mobility) (Slatkin, 1987; Zucker and Darby, 2006; Boschma et al., 2009). Second, local supplier linkages help to minimize transport, transaction, and communication costs, whilst at the same time enabling firms to benefit from a large local supplier market (i.e. the coevolution of specialist subspecies, such as local suppliers, customers, and infrastructure networks within the agglomeration) (Ehrlich and Raven, 1964; Williamson, 1975; Krugman, 1991a; Wal and Boschma, 2010). Third, local knowledge spillovers enable firms within the agglomeration to tap into the latest new knowledge developed within the industry (i.e. local horizontal gene transfer), and also help to create a placedependent industrial atmosphere and local buzz within the surrounding city-region 
(Camagni, 1991; Bathelt et al., 2004; Ridley, 2004; Storper and Venables, 2004). Crucially, these Marshallian (1890) agglomeration economies play an important role within the city-region's economy, as they allow firms within the agglomeration to experience external economies of scale that are external to any single firm, but are internal and place-specific to the agglomeration as a whole.

Ultimately, during the growth stage of the industry life cycle, the firms that rely upon a local pool of skilled labour, maintain local supplier linkages, and receive local knowledge spillovers will experience greater economic performance and increasing returns (Marshall, 1890; Young, 1928). By having a large agglomeration of firms at the growth stage of the industry life cycle, the surrounding region thus benefits from a phenomenal period of economic growth and prosperity, as illustrated by the growth of the metals industry within Sheffield during the late 19th century (Marshall, 1890), the growth of the automotive industry within Detroit during the early 20th century (Klepper, 2007), and the recent growth of the computer industry within Silicon Valley (Saxenian, 1994). However, the rapid growth in the number of firms also causes the returns within the industry to begin to diminish (Klepper, 1996). Similarly, the increasing agglomeration of firms within one locality also causes a number of negative externalities to emerge within the agglomeration, such as higher labour costs, greater land rents, congestion costs, and pollution (Phelps and Ozawa, 2003). Put simply, the growth agglomeration becomes a victim of its own success. Eventually, because of the changes that take place within the industry and the agglomeration, the returns from agglomeration begin to diminish (as shown by the 'decreasing agglomeration economies' from $t_{1}$ to $t_{2}$ in Figure 1). Consequently, the agglomeration starts to spread out across geographical space, which results in the development of a regional supply chain and a regional hub-and-spoke production network (Markusen, 1996) that enables firms in the surrounding region to begin to experience increasing returns from dispersion economies (as represented by the 'increasing dispersion economies' from $t_{1}$ to $t_{2}$ in Figure 1).

\subsection{Mature agglomeration}

Although the rate of evolution varies between different industries, few industries are capable of sustaining growth indefinitely, and the growth stage is eventually succeeded by the mature stage of the industry life cycle (Klepper, 1996). During this period, a number of evolutionary changes occur that cause the industry to mature. First, because of the knowledge codification process, the knowledge within the industry becomes codified and transferable across geographical space with lower transaction costs (Williamson, 1975; Audretsch and Feldman, 1996; Bathelt et al., 2004). Second, due to natural selection, a dominant design emerges within the industry that enables products to become standardized and produced using capital intensive high-volume mass production processes rather than craft production processes (i.e. the standardization process) (Abernathy and Utterback, 1978; Hayes and Wheelwright, 1979; Suárez and Utterback, 1995). Third, a research shift occurs, as firms begin to shift their R\&D emphasis away from a product differentiation strategy that focuses on product innovation and towards a cost-saving strategy that emphasizes production innovation (Klepper, 1997). Finally, a shake out happens, whereby many firms exit the industry and are no longer replaced by new entrants, which ultimately reduces the total number of 
firms within the industry and lowers the agglomeration's biodiversity (i.e. survival of the fittest) (Lieberman, 1990; Agarwal and Gort, 1996).

During this stage of the industry life cycle, the development path of the agglomeration and the surrounding region can become locked in to the path dependent trajectory of the industry life cycle (especially through the competitive exclusion principle or the Upas Tree effect) (Checkland, 1976; Grabher, 1993; Martin and Sunley, 2006). Consequently, the growth agglomeration evolves into a mature agglomeration, within which an increasing number of firms experience diminishing returns from agglomeration economies, especially from a large shake out of firms, the slowdown in industry growth, local market saturation, fierce local competition, and the persistence of local negative externalities (Phelps and Ozawa, 2003). At the same time, the evolutionary changes taking place at the mature stage of the industry life cycle, such as the codification of knowledge, the standardization of products, and lower transaction costs, enable many firms to experience increasing returns from dispersion economies (Audretsch and Feldman, 1996). For instance, motivated by the shift towards costsaving strategies, many of these firms will adapt by dispersing and migrating across geographical space (i.e. biological migration), often towards export markets and lowercost locations outside the city-region (Vernon, 1966; Phelps and Ozawa, 2003). Such a global shift (Dicken, 2003) is often recognized by the emergence within the industry of international branch plants, multinational companies, foreign direct investment, reagglomerations, international supply chains, global pipelines and national and international production networks that connect the agglomeration to new markets and emerging agglomerations within other parts of the world (i.e. a metapopulation) (Dunning, 2000; Watts, 1981; Bathelt et al., 2004; Hanski, 1998). Ultimately, the rise in diminishing returns from agglomeration economies, coupled with the rise in increasing returns from dispersion economies, causes firms to experience similar constant returns from either agglomeration economies or dispersion economies (as represented by the horizontal line $t_{3}$ in Figure 1).

\subsection{Decline agglomeration}

The fourth stage of the industry life cycle is characterized by a period of decline that affects the whole industry, brings benefits to producers and consumers (especially in the form of productivity gains and lower product prices), and has ramifications for the development of the agglomeration and the surrounding city-region (Norton and Rees, 1979; Klepper, 1997). A number of different factors can trigger the decline stage, including a large shake out of firms, intensive price competition, market overcapacity, disruptive innovations, product substitution, exogenous shocks, or unpredictable changes in the supplier or customer markets (i.e. punctuated equilibrium) (Anderson and Tushman, 1990; Deily, 1991; Klepper, 1996; Gould and Eldredge, 1993). This decline stage can be characterized by falling product prices, small profit margins, low firm survival probabilities, a high rate of firm exit from the industry, and the dying out of firms with unfit routines (i.e. firm death) (Londregan, 1990; Lieberman, 1990; Agarwal, 1997). During this period, a large shake out can occur that changes the nature of competition within the marketplace, with some industries experiencing net decreases of $50-80 \%$ of firms (i.e. the extinction process) (Klepper and Grady, 1990; Agarwal and Gort, 2002; Ridley, 2004). Consequently, the firms that remain within the industry, especially the generalist species of firm which are more capable at adaption than 
specialist species, will adapt their routines and place greater emphasis on a variety of new management routines and strategies (i.e. the adaptation process) (Holland, 1992; Teece et al., 1997). These new routines may include geographic relocation (i.e. the speciation process), industry diversification (i.e. hybridization), increasing plant size (i.e. morphology), business mergers (i.e. which can be analogous with sexual reproduction), and acquisitions (i.e. which can resemble predation) (Ricklefs and Miller, 2000; Campbell et al., 2008).

During this period of structural change and the creative destruction of economic landscapes (Schumpeter, 1942; Martin and Sunley, 2006), if a city-region contains an agglomeration of firms that are towards the end of the industry's life cycle, it is likely that Marshall's (1890) trinity of agglomeration economies will decrease the economic performance of firms, create a negative lock-in effect, and generate diminishing returns for the development of the region. First, the firms that continue to depend upon a local pool of skilled labour will specialize in outdated technology, replicate established routines through labour mobility, and experience higher labour costs (i.e. which is analogous to the biological theory of gene flow, whereby established routines continue to flow between different local firms through labour mobility) (Slatkin, 1987; Frenken and Boschma 2007; Maskell and Malmberg, 2007). Second, as a result of symbiosis, the firms that maintain local supplier linkages will become locked in to old supply chain networks of uncompetitive local suppliers that supply outdated, low quality, highly priced products within the agglomeration (i.e. lock-in via coevolution) (Ehrlich and Raven, 1964; Norton and Rees, 1979; Grabher, 1993). Third, the firms that rely upon local knowledge spillovers (i.e. local horizontal gene transfer) will receive out-dated technological knowhow, and will, via the lock-out effect, become locked out of the new knowledge developed by new industries and emerging agglomerations in other parts of the world (i.e. global horizontal gene transfer) (Ridley, 2004; Martin and Sunley, 2006). Consequently, the firms within the city-region are likely to experience diminishing returns from Marshall's (1890) trinity of agglomeration economies on the one hand, but continue to experience increasing returns from dispersion economies on the other (as shown by $t_{4}$ in Figure 1). As a direct consequence, the agglomeration declines in size and causes many firms to adapt by dispersing across geographical space in search of new sources of greater economic performance (i.e. biological dispersal). This will ultimately lead to the development of a Global Production Network (i.e. which can resemble the connectivity found within a biological neural network), a global supply chain, and network economies that are no longer reliant upon the original agglomeration (Bair and Gereffi, 2001; Henderson et al., 2002; Johansson and Quigley, 2004).

Thus, during the later stages of the industry life cycle, Marshall's (1890) trinity of agglomeration economies will no longer generate increasing returns that contribute to the region's development. Quite the opposite, we argue that in the long run Marshall's (1890) trinity of agglomeration economies can decrease the economic performance of firms and create widespread diminishing returns that have a negative impact on the development of the city and the surrounding region (i.e. which will lead to a process similar to ecological succession) (Huston and Smith, 1987). For example, a large shake out of the number of firms within an industry can have a substantial negative impact on the local economy if many of these firms remain agglomerated within a single region (i.e. a local extinction) (Ricklefs and Miller, 2000). When a region contains a large agglomeration of firms that are all experiencing the decline stage of the industry life 
cycle, then the costs of the industry's decline (e.g. deindustrialization, delocalization, divestment, negative profits, firm bankruptcy, restructuring, plant closure, and unemployment) will not be distributed evenly across geographical space, as illustrated by the recent declining agglomerations within the Sheffield metals industry (Watts et al., 2003) and the Detroit automotive industry (Klepper, 2007). Instead, many of these costs are likely to be intensified within one locality and will therefore create a decline agglomeration that can result in a wider regional recession, or even, as Marshall (1890, 273) argued, an 'extreme depression'.

\section{The 'trinity' of research hypotheses}

The theoretical discussion has shown that the evolution of an agglomeration through time and across geographical space can be explained by the evolutionary processes that occur in the industry life cycle. Specifically, we have outlined an Evolutionary Agglomeration Theory (EAT) that explains why Marshall's (1890) agglomeration economies evolve over time in a manner that represents an Agglomeration Life Cycle (ALC) Model. Within this article, we argue that Marshall's (1890) agglomeration economies create greater economic performance and increasing returns during the early stages of the industry life cycle, but declining economic performance and diminishing returns during the later stages of the industry life cycle. To investigate this theory, we aim to examine whether Marshall's (1890) agglomeration economies decrease the economic performance of manufacturing plants during the later stages of the industry life cycle. Consequently, this leads us to three challenging research hypotheses:

Hypothesis $1\left(H_{1}\right)$ : During the later stages of the industry life cycle, relying upon a local pool of skilled labour will decrease the economic performance of firms.

Hypothesis $2\left(\mathrm{H}_{2}\right)$ : During the later stages of the industry life cycle, maintaining local supplier linkages will decrease the economic performance of firms.

Hypothesis $3\left(\mathrm{H}_{3}\right)$ : During the later stages of the industry life cycle, receiving local knowledge spillovers will decrease the economic performance of firms.

\section{Methodological approach}

\subsection{The origin of Marshall's (1890) agglomeration theory}

Historical documents reveal that Marshall's (1890) agglomeration theory originated from the face-to-face interviews he conducted with managers from manufacturing plants within Sheffield (in the United Kingdom) (Groenewegen, 1995; Becattini, 2006). Consequently, within the economic geography literature, over 80 economists, geographers and economic historians agree that the Sheffield metals industry is where Marshall (1890) discovered his trinity of agglomeration economies: a local pool of skilled labour, local supplier linkages, and local knowledge spillovers. The long list of authors who have emphasized that Marshall's (1890) agglomeration theory originated from his analysis of the Sheffield metals industry includes many economists, such as Krugman (1991a), Krugman and Obstfeld (2009), Venables (1999), Fujita et al. (1999), Duranton and Overman (2005), Matouschek and Robert-Nicoud (2005), Dunning (2000), and Rosenthal and Strange (2004), and geographers, such as Storper (1989), 
Scott (1999), Bathelt et al. (2004), Harrison (1992), Simmie (1997), Becattini (2006), Lee (2000), Amin (2002), Cooke (1990) and Sabel and Zeitlin (1985). For example, Krugman and Obstfeld $(2009,140)$ argue that 'the analysis of external economies goes back more than a century to the British economist Alfred Marshall, who was struck by the phenomenon of 'industrial districts' - geographical concentrations of industry that could not be explained by natural resources. In Marshall's time, the most famous examples included such concentrations of industry as the cluster of cutlery manufacturers in Sheffield...' Importantly, Sheffield was the only place where Marshall (1890) argued that all three of his 'trinity' of agglomeration economies existed, as the following passages show clearly:

(i) A local pool of skilled labour:

The leadership in a special industry, which a district derives from an industrial atmosphere, such as that of Sheffield or Solingen, has shown more vitality than might have seemed probable in view of the incessant changes of technique. The explanation is perhaps to be found in the fact that an established centre of specialized skill...

(Marshall, 1919, 190).

(ii) Local supplier linkages:

Or there may be a movement towards intermediate plans, similar to those which are largely followed in the Sheffield trades. Many cutlery firms for instance put out grinding and other parts of their work, at piece-work prices, to working men who rent the steam power which they require, either from the firm from whom they take their contract or from someone else: these workmen sometimes employing others to help them, sometimes working alone.

(Marshall, 1890, 296).

(iii) Local knowledge spillovers:

Sheffield and Solingen have acquired industrial 'atmospheres' of their own; which yield gratis to the manufacturers of cutlery great advantages, that are not easily to be had elsewhere: and an atmosphere cannot be moved.

(Marshall, 1919, 176).

Economic historians have also recently identified how Marshall's (1890) agglomeration theory evolved from the field research he conducted within the Sheffield metals industry (Groenewegen, 1995; Raffaelli et al., 2006). According to Marshall's personal records, diaries and field notes that are held at the Alfred Marshall Library at the University of Cambridge, he began his research within Sheffield in the autumn of $1885^{2}$ (Groenewegen, 1995). During his research within Sheffield, Marshall interviewed managers from a wide variety of manufacturing plants in the metal file, metal armour plating, razor, metal steel, cutlery, and metal tool industries. In particular, Marshall interviewed managers from a number of large manufacturing plants, such as Stevenson's metal foundry works, Sorbey's metal saw works, and Jessop's metal steel works (Tweedale, 1995). Consequently, many economic historians conclude that Marshall's (1890) agglomeration theory can be linked directly to the face-to-face interviews he undertook within the Sheffield metals industry, especially because Marshall's (1890) famous text The Principles of Economics, with a whole chapter dedicated to the localization of industries, was completed soon after he finished his

2 For example, the initial impression of Mary Marshall, who was Alfred Marshall's wife and scholarly partner, upon arriving within Sheffield was that it was "black but picturesque", a likely reference to the large amounts of pollution produced by the metal furnaces within the manufacturing town during this period (Groenewegen 1995: 211). 
research within Sheffield (Groenewegen, 1995). Moreover, Marshall (1919, 373) held the Sheffield metals industry with such high regard that he commented 'Sheffield is the home of some of the most delicate of British steel industries; and also of those which are beyond the range of any but a mammoth business: and Sheffield is in all these respects an epitome of Britain.'

\subsection{The metals industry life cycle}

Today, the metals industry is one of the largest and most geographically dispersed industries in the world, with a global supply chain and Global Production Network that spans many developed and developing countries (Chinitz, 1961; Deily, 1991; Grabher, 1993; Henderson et al., 2002; Sadler, 2004). From a historical perspective, however, many argue that the metals industry evolved from a series of radical innovations that were developed within the agglomeration of manufacturing plants in Sheffield around the same time Marshall (1890) conducted his research within the manufacturing town (Groenewegen, 1995; Hey, 2005). Marshall's (1890) interest in Sheffield was no accident: during this period, Sheffield was the Silicon Valley of the Industrial Revolution, and created many radical innovations such as Crucible Steel, Sheffield Plate Metal, the Bessemer Steel Converter, and Manganese Steel, which in turn helped generate a large agglomeration of metal manufacturing plants within the city-region (Hey, 2005). For example, leading up to Marshall's research within Sheffield, the agglomeration of manufacturing plants within the region had monopolized the metal steel industry, producing $90 \%$ of the total metal steel output of Britain and $50 \%$ of the total metal steel output of both Europe and North America (Tweedale, 1995). Consequently, this large metals agglomeration locked the development path of the cityregion into the life cycle of the metals industry. Importantly, it was during this period of rapid economic growth during the early stages of the industry life cycle that Marshall (1890) studied the city-region and discovered that increasing returns were being generated from a trinity of agglomeration economies.

However, during the early 20th century, Marshall (1919) noted that many of the industrial districts he used as examples of how agglomeration generates increasing returns were beginning to mature and eventually decline during the later stages of their life cycle. Uniquely, at the start of the 21st century, a large metals agglomeration still exists within Sheffield and the surrounding region of South Yorkshire (Watts et al., 2003). Fortunately, for Sheffield, a further radical innovation was invented within the city which extended the industry life cycle and provided a new development trajectory to the metals agglomeration and the surrounding city-region. This radical innovation was the metal: stainless steel, which is an iron-carbon metal alloy that does not rust, corrode or stain, and was invented by Harry Brearley in 1912 in the city of Sheffield (Tweedale, 1995). Consequently, the metals agglomeration continued to grow and mature by specializing in the production of stainless and specialist metals, until it too entered the decline stage of its life cycle towards the end of the 20th century (Watts, 1991).

Somewhat ironically, during the 1980s and 1990s, whilst many economists and geographers were busy using Marshall's (1890) agglomeration theory to argue that agglomeration economies generate increasing returns (Porter, 1990; Krugman, 1991a; Fujita et al., 1999), few noticed that during this period the same agglomeration as that on which Marshall (1890) based this theory has also caused one of the largest and most 


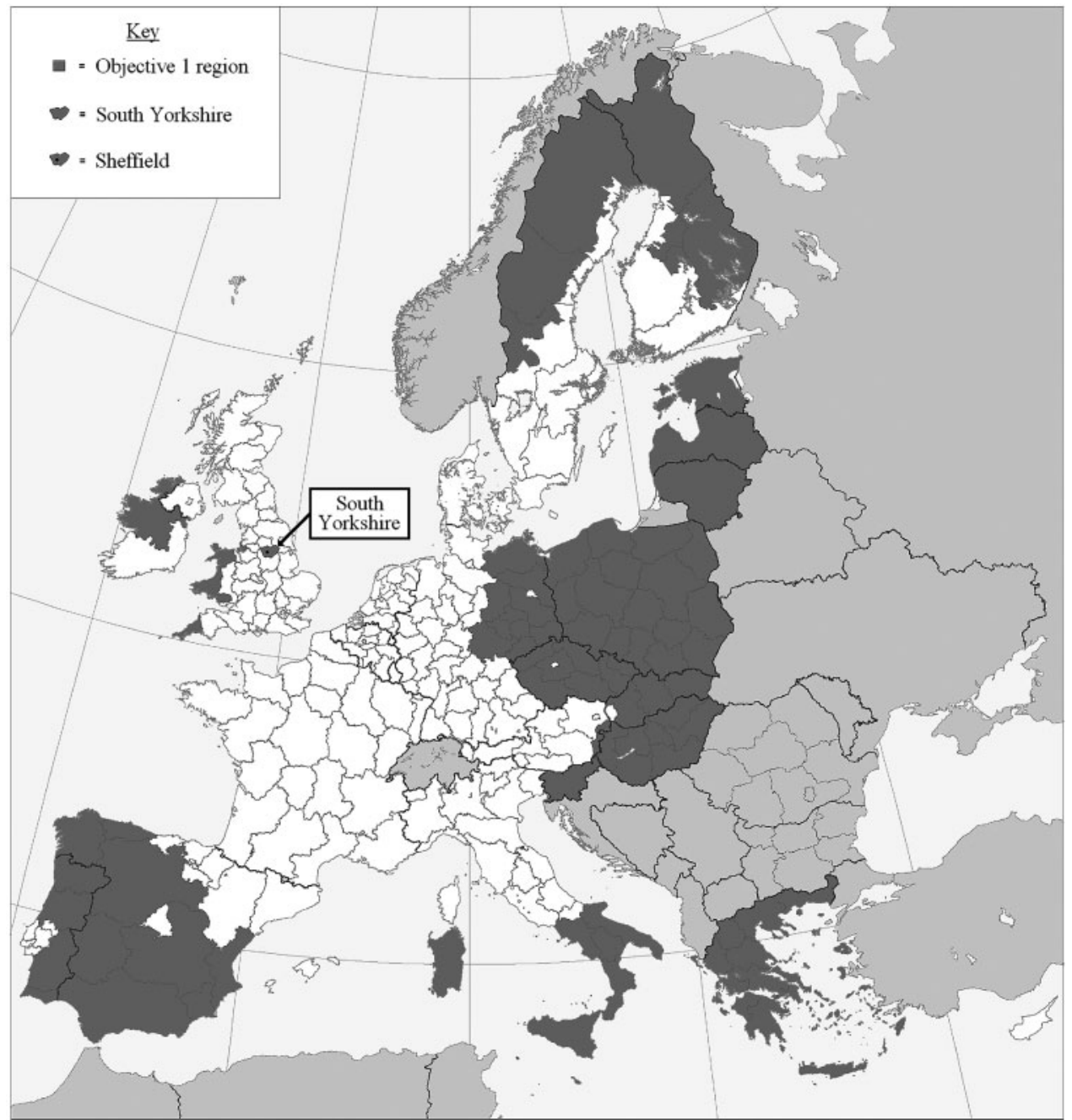

Figure 2. Europe's lagging regions: the Objective 1 regions within the EU (2000-2008). Notes: Sheffield is the fifth largest city within England, and the surrounding region of South Yorkshire has a total population of 1.4 million people. However, it is also one of the poorest regions within Europe, after its GDP per capita fell to below $75 \%$ of the EU(15) average, formally qualifying it as an Objective 1 region (European Commission, 2005).

sustained economic declines in European history. Consequently, the city of Sheffield and the surrounding region of South Yorkshire were formally recognized in the first years of the 21st century as one of the poorest regions within the whole of Europe (Figure 2) (European Commission, 2005). For example, between 1979 and 1995, the GDP per capita of the region, compared to the EU-15 average, declined every year for 16 consecutive years, which culminated in the GDP per capita of the region declining to less than $75 \%$ of the EU-15 average in the late 1990s (European Commission, 2005). This sustained economic decline formally qualified the region for Objective 1 status, which confers the highest level of eligibility for development aid from the European 
Commission, and the region has received $£ 2.4$ billion ( $\$ 4.8$ billion) in regional development investment from the European Commission, the UK government, and private contributors for the 2000-2008 programme period.

\subsection{Data collection}

In order to examine our research hypothesis that Marshall's (1890) agglomeration economies are generating diminishing returns for economic performance we collected and analysed empirical data from a large cross-section of manufacturing plants in the manufacturing sector (including a subset of plants within the metals industry) from within the South Yorkshire city-region. Throughout the 20th century, the manufacturing plants that Marshall (1890) studied, and the agglomeration as a whole, have expanded in size (Watts, 1991; Watts et al., 2003). Therefore, to determine whether Marshall's (1890) agglomeration economies decrease economic performance, we collected plant-level data from a large sample of medium and large manufacturing plants within the South Yorkshire city-region, following formal definitions by the Standard Industrial Classification (2003) and the European Commission (2005). Plantlevel data enabled us to collect detailed data on individual manufacturing plants, as opposed to aggregated firm-level data that may be biased because of the inclusion of plants that are not in the manufacturing industry or located within the city-region (e.g. multi-site firms, group companies, or multinational enterprises) (Watts, 1991).

Medium and large manufacturing plants were selected because we are aiming to replicate as closely as possible the original study that Marshall (1890) conducted within the city-region. During his research within the city-region, Marshall (1890) paid close attention to the large manufacturing plants, and conducted many face-to-face interviews with managers from a number of large plants from both the manufacturing sector and the metals industry in particular. Following the same approach as Marshall (1890), we conducted face-to-face interviews with managers of local manufacturing plants from a wide variety of industries in the manufacturing sector and the metals industry. Such an approach enabled us to collect detailed empirical data from a number of the manufacturing plants that Marshall (1890) studied when he conducted his faceto-face interviews within the city-region, and from a large number of firms established within the city-region at around the same time. Within this study, we focus on medium and large manufacturing plants because they also account for the majority of the manufacturing employment within the city region, some $68 \%$, and are still overrepresented within the city-region. For example, location quotient analysis reveals that, in comparison to the national average, the city-region contains a significant overrepresentation of medium and large manufacturing plants (NOMIS, 2005; PA1003, $2005)^{3}$. In addition, the city-region also contains a significant over-representation of manufacturing plants within the metals industry. Importantly, the over-representation

3 Location Quotient Analysis (i.e. manufacturers by employment size band, South Yorkshire compared to the national average):

- 50-99 employees (LQ = 1.25)

- 100-199 employees (LQ = 1.50)

- 200-499 employees (LQ $=2.00)$

- 500-999 employees (LQ = 1.25) 
of these larger manufacturing plants within the metal industry is primarily the outcome of the evolution of the Agglomeration Life Cycle ( $A L C$ ) Model, as during the later stages of the life cycle it is common to find that many of the original manufacturers have expanded the size of their plants. Consequently, the economic performance of medium to large manufacturing plants within the metals industry was a key priority for policy makers within the European Commission who were concerned about the economic risk this agglomeration of large declining plants within this industry placed on the development trajectory of the city-region.

A total population of 367 such manufacturing plants was identified from secondary data sources (Companies House, 2005) and local field work within the city-region, which was cross-referenced with similar research conducted by the European Commission (2005). In all, managers from 79 manufacturing plants within the region were interviewed using a semi-structured interview schedule that had already been pilot tested. Overall, the sample represents a response rate of $22 \%$. In particular, this includes a number of the manufacturing plants that Marshall (1890) studied, and a large number of firms established within the region at around the same time (Tweedale, 1995). Furthermore, our sample accounts for a large proportion, some $25 \%$, of employment within the manufacturing sector within the city-region (PA1003, 2005). Although twoby-two chi-square tests indicate that our sample is representative of the population of manufacturing plants within the city-region with respect to industry ${ }^{4}$ and geographical location, ${ }^{5}$ it is worth noting that larger manufacturing plants are overrepresented. ${ }^{6}$

\subsection{Measures}

\subsubsection{Local pool of skilled labour}

The first of Marshall's (1890) agglomeration economies was measured by asking respondents about the skill level of the workforce employed at the manufacturing plant. Highly skilled employees were defined as employees trained at university degree level (or to the industry's own equivalent standard) such as formally qualified engineers, researchers, technologists, or scientists (Robson and Bennett, 2000; Boschma et al., 2009). Importantly, this approach to measuring employee skills has been used by a number of empirical studies within economics, geography and the wider social sciences (Koser and Salt, 1997; Robson and Bennett, 2000; Boschma et al., 2009). Our rationale is that manufacturing plants with a highly skilled workforce are more likely to rely upon a local pool of skilled labour, which is one of the defining characteristics of Marshall's (1890) trinity of agglomeration economies. To ensure measurement accuracy, respondents were asked to use the internal payroll list of their manufacturing plant to calculate what percent of their employees were highly skilled. During the interviews, many respondents emphasized that they relied heavily upon a local skilled labour market, and this reliance was especially apparent within the metals industry because of the local concentration of skilled engineers, researchers, and scientists trained in metallurgy, materials science and the engineering sciences.

4 Industry: $\chi^{2}=1.97$; critical value $=7.82 ;$ d.f. $=3 ; P=0.05$, two-tailed test.

5 Location: $\chi^{2}=2.0$; critical value $=7.82 ;$ d.f. $=3 ; P=0.05$, two-tailed test.

6 Plant size: $\chi^{2}=20.34$; critical value $=5.99 ;$ d.f. $=2 ; P=0.05$, two-tailed test. 
Admittedly, using plant level data is less satisfactory than detailed census level data, but an overall analysis of employee skills across the city-region was outside the scope of our study. Whilst our measure of employee skill is consistent with measures used in regional, national, European, and international surveys, it is, of course, not without its limitations. Just as Marshall (1890) did, we are making the assumption that the majority of employees are hired from and reside within the South Yorkshire region. A further assumption is that, like Marshall's (1890) original study, we are assuming that plants employing highly skilled employees are likely to rely upon a local pool of skilled labour, which is in keeping with past empirical research within the city-region (Tweedale, 1995; Watts et al., 2003). However, it should be acknowledged that this may not apply to all the manufacturing plants, as younger firms, branch plants and greenfield investments are less likely to rely upon the existing skill base within the region (Dunning, 2000). In view of these concerns, our interpretation of the results relating to the local pool of skilled labour proceeds cautiously.

\subsubsection{Local supplier linkages}

We measured the second of Marshall's (1890) trinity of agglomeration economies by asking respondents a series of detailed questions about the degree of linkage between their manufacturing plant and local suppliers within the region (Hirschman, 1958). We expect that manufacturing plants with greater local supplier linkages are more likely to depend upon a local supplier market, which Marshall (1890) identified within the cityregion. Three variables were used to measure the degree of local supplier linkage. The initial measure focuses on whether manufacturing plants source materials or components from any local suppliers located within the city-region ( $\mathrm{LSL}_{1}$ ) (Watts et al., 2003). The second measure concerns whether plants source from a local key supplier within the city-region that accounts for $5 \%$ or more of their expenditure on materials and components $\left(\mathrm{LSL}_{2}\right)$ (Crone and Watts, 2003). The third measure is the percentage of the expenditure of the manufacturing plant (by value) on materials and components sourced from local suppliers within the city-region ( $\left.\mathrm{LSL}_{3}\right)$ (Hewitt-Dundas et al., 2005). During the interviews, many managers explained that although there had been a long history of local sourcing within the metals agglomeration, many firms were adapting by shifting from local sourcing to global sourcing because of the cluster's decline (i.e. supply chain evolution).

\subsubsection{Local knowledge spillovers}

The last of Marshall's (1890) trinity of agglomeration economies focuses on the extent of local knowledge spillover within the city-region, what Marshall $(1919,176)$ described as Sheffield's unique 'industrial atmosphere'. Since Krugman's (1991a, 53) declaration that knowledge spillovers '. . are invisible; they leave no paper trail by which they may be measured and tracked', the measurement and importance of local knowledge spillovers has attracted some considerable debate within economic geography (Jaffe et al., 1993; Martin and Sunley, 1996). In response to Krugman's (1991a) comments, Jaffe et al. $(1993,578)$ point out that 'knowledge flows do sometimes leave a paper trail' in the form of patent citation data. However, using patents as approximations for local knowledge spillovers has the potential to introduce a substantial bias towards R\&D spillovers from growing firms at the start of the Agglomeration Life Cycle (ALC) Model. 
Conversely, we still do not know what impact local knowledge spillovers have towards the end of the Agglomeration Life Cycle (ALC) Model, especially within the context of a declining agglomeration (Martin and Sunley, 2003).

To overcome these limitations, we asked respondents whether their manufacturing plant had received knowledge from any local organization located within the region's manufacturing industry within the past 3 years, such as from local customers, material input suppliers, machinery, equipment or tool suppliers, service suppliers, or other local manufacturing plants (Crone and Roper, 2001; Potter et al., 2003). Local knowledge spillovers were defined as knowledge the manufacturing plant valued at a minimum of one thousand pounds sterling (i.e. approximately \$1850), or the equivalent of 5 days of inter-firm knowledge transfer. Importantly, this definition of a local knowledge spillover allows us to distinguish knowledge that respondents regard as having an underlying value from codified information that is exchanged frequently between firms (Breschi and Lissoni, 2001). Furthermore, to verify these local knowledge spillovers, respondents were also asked to describe in detail the types of knowledge they had received. Within this study, the majority of local knowledge spillovers consisted of technical, technological, or scientific knowledge related to the metal steel industries. Although this measure does not capture the effect of region-specific untraded interdependencies, relational norms or local buzz (Bathelt et al., 2004; Storper and Venables, 2004), it does capture Marshall's (1890) original notion of local knowledge spillovers, and it does ensure measurement consistency by standardizing the measurement of local knowledge spillover from different local organizations.

\subsubsection{Economic performance}

During the interviews, respondents kindly agreed to allow us access to the financial accounts of their manufacturing plants for the previous 3 years and, in many cases, confidentiality agreements were signed to ensure access to this sensitive economic data. Using this detailed plant-level data enabled us to measure the impact of agglomeration economies on economic performance to a greater degree of detail than that achieved by earlier empirical studies, which often had to rely upon aggregated data at the firm level or regional scale. Furthermore, by cross-referencing the data from the internal financial accounts of the plant with that from registered public financial accounts, annual financial reports, and data from secondary sources, we were able to measure economic performance to a high degree of accuracy. The measures of economic performance used in this study include: cost performance (i.e. material costs, labour costs, total costs, cost growth and productivity), sales performance (i.e. sales turnover, turnover growth, and price competitiveness), and profit performance (i.e. profitability, profit margin, profit growth and employment growth). This resulted in the creation of a large number of multivariate models; therefore the following discussion focuses on the models that identified a statistically significant relationship between Marshall's agglomeration economies and economic performance.

\subsection{Empirical analysis}

Within this study, we used a two-step approach to the empirical analysis. First, we used multivariate regression analysis to investigate whether each of Marshall's (1890) trinity of agglomeration economies decreases the economic performance of all manufacturing 
plants within the manufacturing sector of the city-region. Importantly, this enables us to replicate as closely as possible the original study that Marshall (1890) undertook within the city-region, which focused on interviewing managers of manufacturing plants from a variety of industries. Second, we focused upon a sub set of manufacturing plants within the metals industry where, because of the smaller number of such plants, we used bivariate regression analysis. This two step approach allows us to examine whether Marshall's agglomeration economies are presently generating diminishing returns for the whole manufacturing sector within the city-region, or are confined to the metals industry, as the Agglomeration Life Cycle ( $A L C$ ) Model would suggest. Further details of the bivariate regression analysis that is used to analyse manufacturing plants within the metals industry can be found within Section 5.4.

In our multivariate regression analysis, each model contains a dependent variable that measures economic performance, which is then followed by a series of independent variables that include one of our three measures of Marshall's (1890) trinity of agglomeration economies and a number of control variables. In situations where the measure of economic performance was an interval measure, we used a multivariate ordinary least squares (OLS) regression model (Greene, 2008). Where the economic performance measure was dichotomous, we used a multivariate logistic regression model, which uses a maximum likelihood estimation method (Gujarati, 2005). Within all of our models, we controlled simultaneously for the impact of a series of control variables, including plant size, plant age, competition, export intensity, patent innovation, and multinational ownership (more details of these variables can be found in the Appendix) (Robson and Bennett, 2000; Malmberg et al., 2000; Dunning, 2000). Overall, multicollinearity analysis and assumption tests indicate that our multivariate models remain robust, and their ability to explain variations in economic performance is in accordance with similar empirical studies (Kennedy, 2003). Although some of the results from the models may initially seem to have a low level of model fit, they are in keeping with similar empirical research into the determinants of economic performance, which often experience low levels of model fit (Greene, 2008). However, it should be noted that Marshall's (1890) agglomeration economies appear to only have a marginal effect on economic performance, which illustrates that their importance has diminished over time, especially as the agglomeration has declined in size within the city-region.

\section{Econometric results: when agglomeration generates diminishing returns}

\subsection{Declining agglomeration: the negative impact of a local pool of skilled labour}

We begin by examining whether the first of Marshall's (1890) trinity of agglomeration economies - a local pool of skilled labour-decreases the economic performance of manufacturing plants within the city-region. To recap, respondents were asked during the interviews to quantify the percentage of their employees that are highly skilled (Robson and Bennett, 2000; Boschma et al., 2009). On average, a mean and median of $50 \%$ of employees were identified as highly skilled. Using this data in conjunction with data collected on the characteristics of the manufacturing plants and their economic performance, we then created a series of multivariate regression models. The empirical results from these models provide some support for our first research hypothesis, and 
indicate that relying on skilled labour decreases the economic performance of manufacturing plants. Specifically, the results in Tables 1 and 2 demonstrate that manufacturing plants with highly skilled employees are statistically more likely to experience higher labour costs and higher total costs. Furthermore, these empirical results remain statistically significant at the $95 \%(P<0.05)$ and $99 \%(P<0.01)$ levels, respectively, whilst controlling simultaneously for the influence of a series of control variables. These empirical results indicate that reliance upon skilled labour does indeed decrease the economic performance of the manufacturing plants within the city-region. However, as noted in Section 4.4, we need to be cautious in linking the poor economic performance of manufacturing plants with a reliance on a local skilled workforce.

One possible explanation for these results is that although the employees are highly skilled, they may be skilled in outdated routines, discontinued technologies and established knowledge, and importantly, may have become locked-out of the new knowledge to emerge from late-movers into the industry (Lieberman and Montgomery, 1988; Martin and Sunley, 2006). Furthermore, it may be the case that during the later stages of the Agglomeration Life Cycle (ALC) Model the types of skills demanded by the industry change as a result of knowledge codification, product standardization, capital intensive production, vertical integration, and disruptive innovations, so that the supply of skills within the agglomeration are no longer valued as much as they once were (Scott, 1983; Phelps and Ozawa, 2003). In light of all of this, the inward migration of highly skilled employees, such as entrepreneurs, star scientists, and key engineers from new industries and emerging agglomerations that are located outside of the region may be one of the ways to transfer and infuse new knowledge into the lagging region (i.e. which is analogous to the biological theory of gene flow, whereby new routines flow into the region through inward migration) (Boschma et al., 2009; Slatkin, 1987; Womack et al., 1990).

\subsection{Declining agglomeration: the negative impact of local supplier linkages}

To recall, we used three different variables to measure the degree of linkage between manufacturing plants and local suppliers within the city-region. We found that $64 \%$ of manufacturing plants source locally from suppliers within the city-region $\left(\mathrm{LSL}_{1}\right)$ and, in particular, some $43 \%$ of manufacturing plants source from a key supplier that is based locally $\left(\mathrm{LSL}_{2}\right)$. Examples of these local key suppliers included metal input suppliers, large metal steel producing plants, metal processing plants, metal rolling mills, and metal foundries, casters and forgers. In addition, the third measure of local supplier linkage focuses on the percentage of materials expenditure spent locally $\left(\mathrm{LSL}_{3}\right)$, which illustrates that manufacturing plants source a mean of $17 \%$ and a median of $4 \%$ of their materials from local suppliers within the city-region. The skewed distribution of this data suggests that whilst many manufacturers source only a small proportion of their materials from local suppliers, a group of manufacturing plants with substantial local supplier linkages exists, especially with respect to key suppliers within the region. In addition, because of the non-normal distribution of the third measure of local supplier linkage $\left(\mathrm{LSL}_{3}\right)$, there is a clear statistical rationale for using the second measure $\left(\mathrm{LSL}_{2}\right)$ within the multivariate analysis (i.e. key supplier within the region). These results are similar to earlier studies, which found that local supply chain linkages tend to be comparatively weak, especially within mature and declining agglomerations, even 


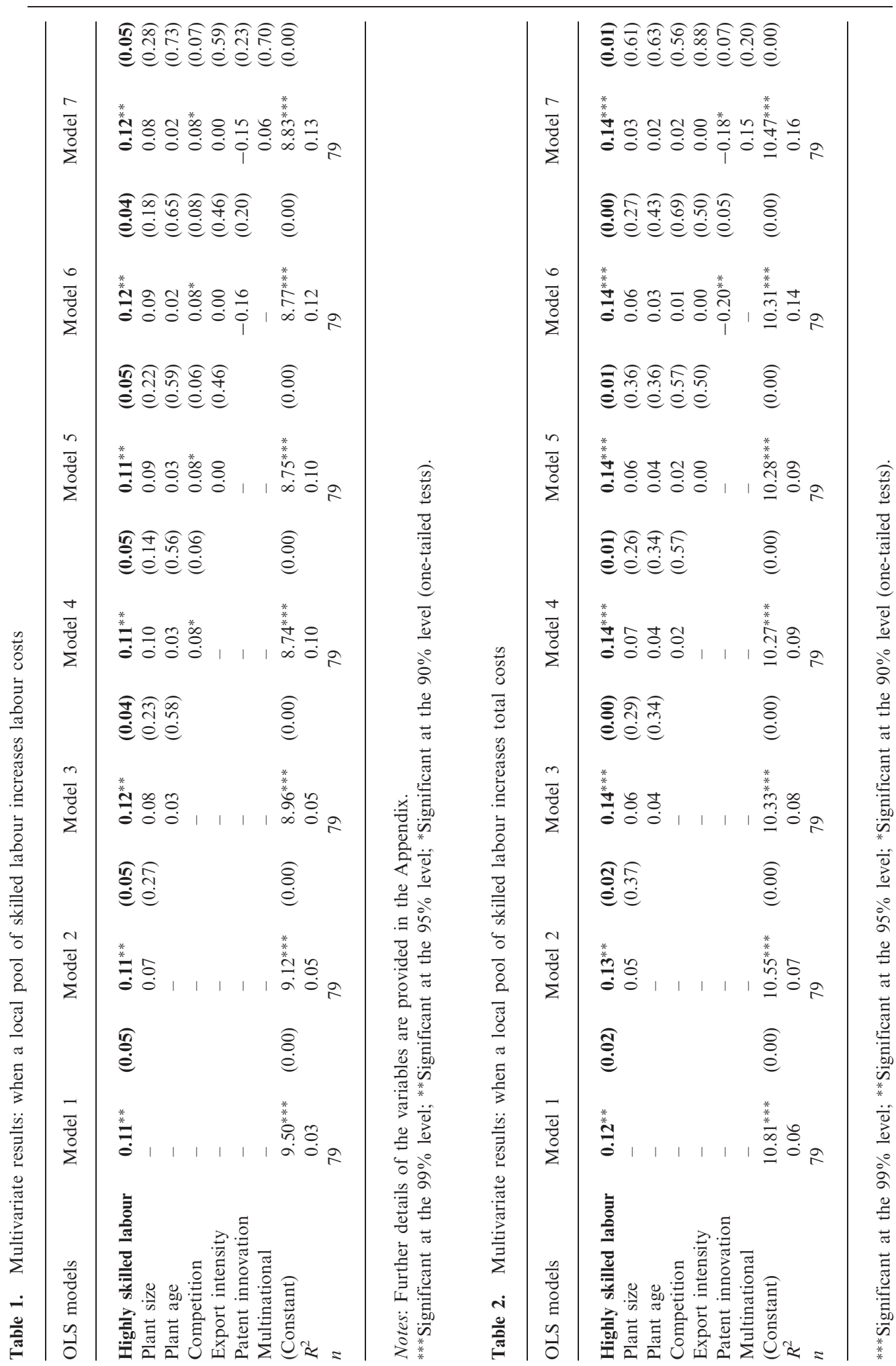


though there remains a degree of spatial clustering activity (Lever, 1972; Watts, 1981; Phelps, 1992; Watts et al., 2003).

To examine whether the different measures of local supplier linkage could influence the results from the multivariate analysis, each of the three measures was included in separate multivariate models. These results clearly demonstrate that maintaining linkages with key suppliers within the city-region decreases the economic performance of manufacturing plants (i.e. $\mathrm{LSL}_{2}$ ). First, manufacturing plants with local supplier linkages to key suppliers within the region are more likely to have experienced cost growth over the previous 3 years, a relationship that remains statistically significant at the 95\% level $(P<0.05)$ (Table 3$)$. Second, sourcing from key suppliers within the cityregion not only increases the likelihood of cost growth, but more importantly, it also decreases the plant's profit margin, a negative relationship that is also statistically significant at the $95 \%$ level $(P<0.05)$ (see Table 4). Finally, further multivariate analysis reveals that sourcing from key local suppliers also reduces the likelihood of profits growth $(P<0.10)$ and profitability $(P<0.05)$. Whilst acknowledging the limitations of our analysis, it appears that many plants continue to be locked-in to old supply chain networks of uncompetitive local suppliers that supply comparatively highly priced products that have a negative impact on economic performance, and this concern was also mentioned by many of the managers we interviewed. Further analysis also reveals that sourcing from key suppliers has no significant beneficial impact on any of the measures of economic performance used in this study, which is in contrast to many theories and policies that emphasize the importance of local sourcing and clustering to firm performance and regional development (Porter, 1990; Krugman, 1991b). Consequently, manufacturing plants are likely to adapt by breaking up these redundant linkages to the local supplier market that coevolved within the city-region (i.e. adaptive behaviour), which will decrease the network centrality and connectivity of the agglomeration within the industry and along the supply chain (i.e. supply chain evolution) (Wal and Boschma, 2010). In many ways, these results are similar to early research by Grabher (1993) into the weakness of strong ties within the Ruhr Valley metal steel industry, Martin and Sunley's (2006) theoretical analysis of the negative lock-in effect, and Johansson and Quigley's (2004) recent discussion of the substitution of agglomeration economies by network economies.

\subsection{Declining agglomeration: the negative impact of local knowledge spillovers}

Finally, we now explore the last of Marshall's (1890) trinity of agglomeration economies: local knowledge spillovers. Here we test our final research hypothesis that local knowledge spillovers decrease the economic performance of manufacturing plants during the later stages of the Agglomeration Life Cycle (ALC) Model. The empirical results indicate that all the manufacturing plants within our research had formed local linkages with at least one local organization within the local manufacturing industry in the city-region, and that $32 \%$ of manufacturing plants had received a local knowledge spillover from them in the past 3 years. These results suggest that a group of manufacturing plants continues to rely upon local knowledge spillovers from within the city-region. Broadly speaking, although an industrial atmosphere of local knowledge spillovers still exists within the region, it has been diminishing over time and currently represents a diminishing industrial atmosphere rather than the rich industrial atmosphere that Marshall (1890) identified. Tables 5 and 6 outline the results from the multivariate 


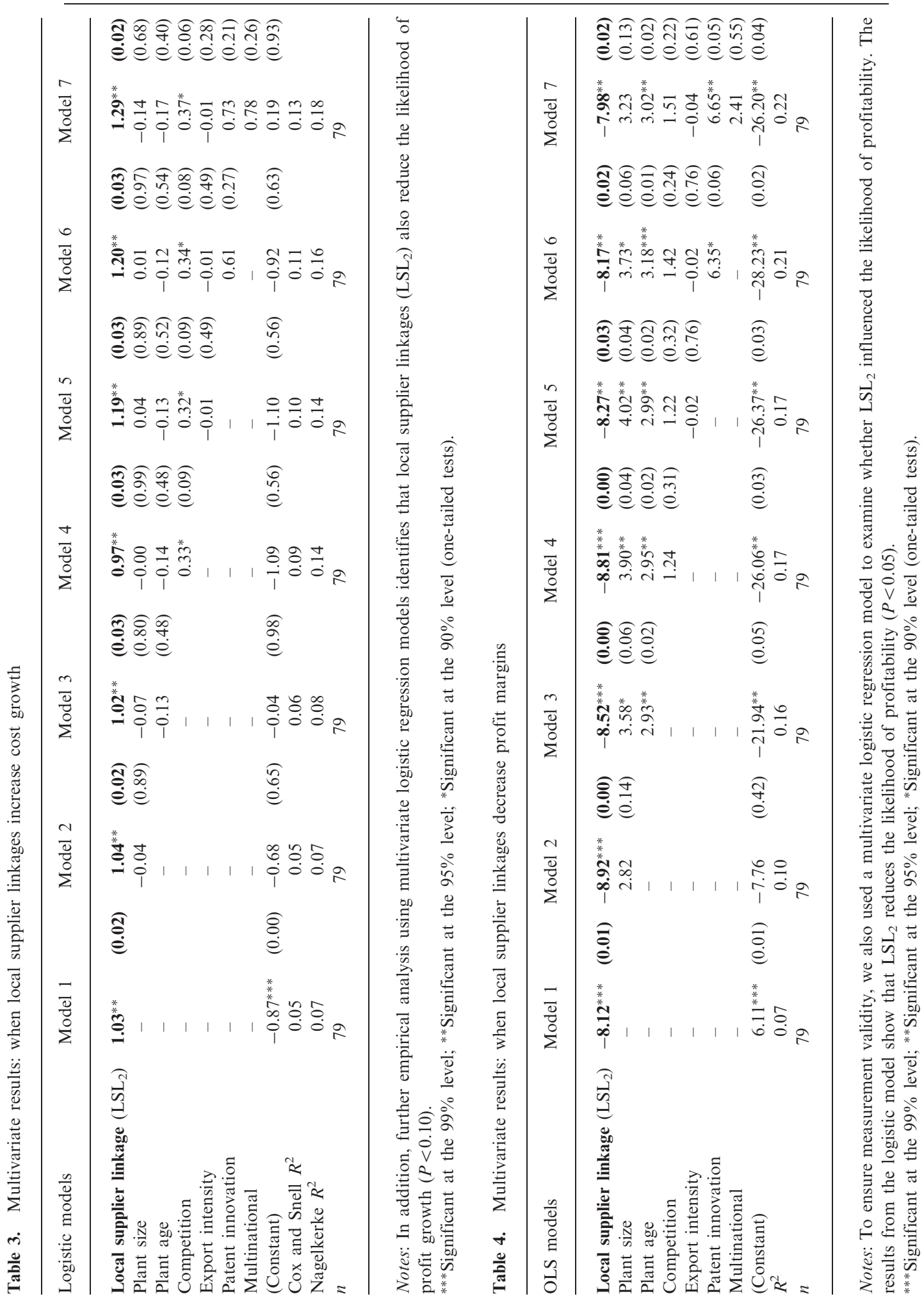




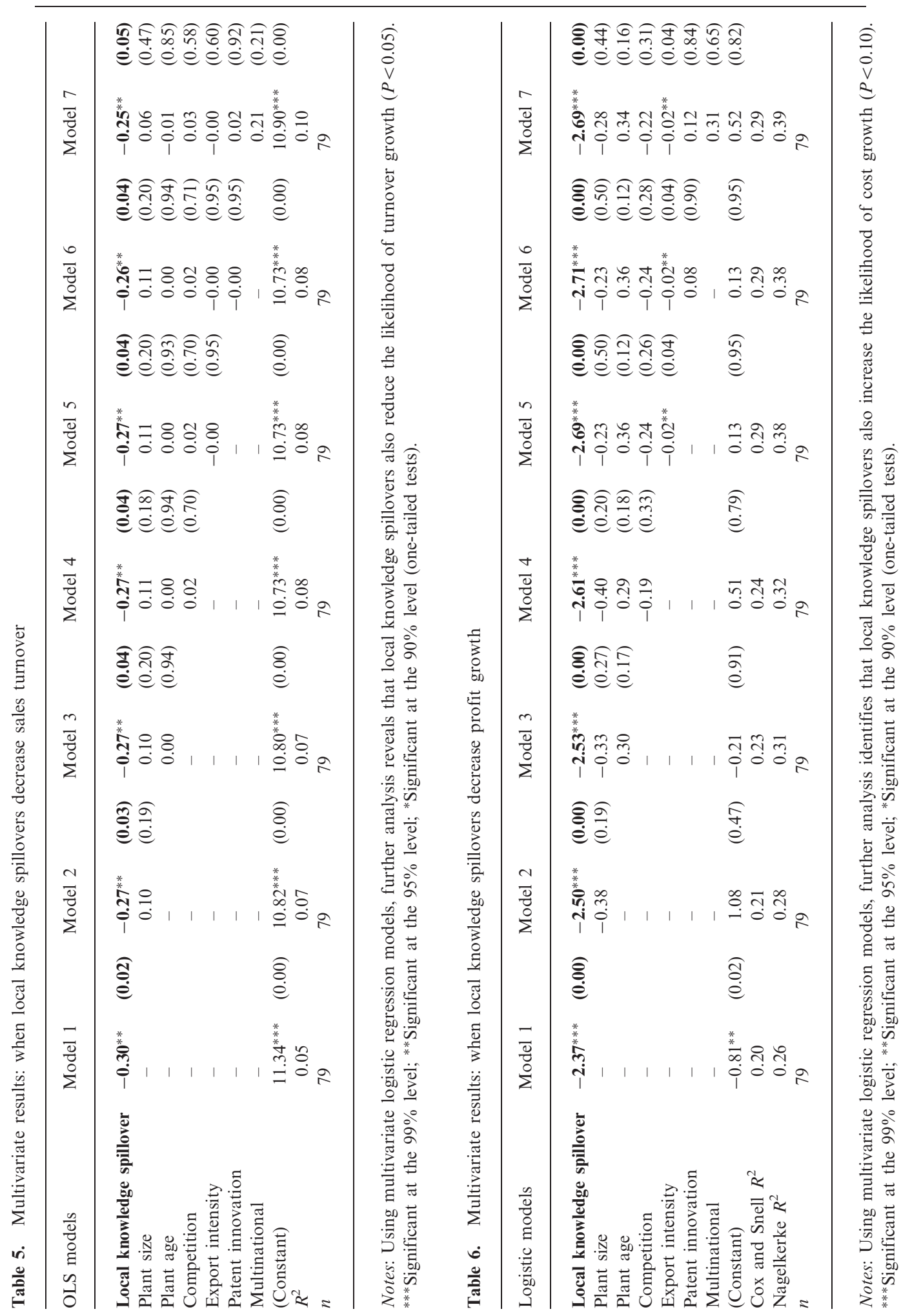

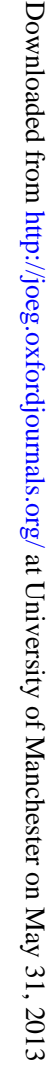


analysis, which indicate that local knowledge spillovers decrease economic performance, and importantly, do not have any statistically significant beneficial impact on the manufacturing plants. All other things being equal, manufacturing plants that receive local knowledge spillovers generate lower sales turnover and are also less likely to experience profit growth. The negative impact of local knowledge spillovers on sales turnover is statistically significant at the 95\% level $(P<0.05)$, and the negative impact of local knowledge spillovers on profit growth is statistically significant at the $99 \%$ level $(P<0.01)$. In addition, further multivariate analysis illustrates that local knowledge spillovers also reduce the likelihood of turnover growth $(P<0.05)$, and increase the likelihood of cost growth $(P<0.10)$.

Importantly, these results indicate that local knowledge spillovers, which are often assumed to be the primary drivers of increasing returns and economic development (Romer, 1986; Griliches, 1992; Jaffe et al., 1993), can, under certain circumstances, decrease the economic performance of manufacturing plants and potentially lead to diminishing returns for regional development. Somewhat ironically, these results are drawn from the same city-region which Marshall (1890) described as having a rich 'industrial atmosphere', and which many economic geographers regard as the first archetypal example of the benefits of local knowledge spillovers. Conversely, during the later stages of the Agglomeration Life Cycle ( $A L C$ ) Model, it appears that many of the firms within the declining agglomeration have adapted their supply chain linkages by relying upon global pipelines (Bathelt et al., 2004), global value chains (Bair and Gereffi, 2001) and global production networks (Henderson et al., 2002) to receive new knowledge transfers (i.e. global horizontal gene transfer). These new knowledge transfers often originate from late movers into the industry, and from firms located in new industries and emerging agglomerations in other parts of the world. For example, many respondents highlighted that they had recently adapted by implementing Japanese management practices that originate from the automotive industry, such as Lean Production, Just in Time delivery, Kaizen continuous improvement, and Total Quality Management (Womack et al., 1990).

\subsection{Marshall's (1890) agglomeration economies and the industry life cycle}

In summary, the empirical results from the multivariate regression analysis appear to indicate that Marshall's (1890) agglomeration economies are decreasing the economic performance of plants within the manufacturing sector of the city-region. In total, within the manufacturing sector, Marshall's (1890) agglomeration economies are found to have 10 significant negative impacts on economic performance. It appears that none of Marshall's (1890) trinity of agglomeration economies has any significant beneficial impact on the economic performance of manufacturing plants whatsoever, which is in contrast to the large number of theories and policies within economic geography that emphasize such a relationship (Porter, 1990; Krugman, 1991a; Fujita et al., 1999). During the later stages of the Agglomeration Life Cycle ( $A L C$ ) Model, manufacturing plants improve their economic performance when they reduce their dependence upon a local pool of skilled labour, break up redundant local supplier linkages, and reduce their reliance upon local knowledge spillovers. However, we still need to investigate whether the negative impact of Marshall's (1890) agglomeration economies on economic performance is affecting the whole manufacturing sector, or whether, as 
our theory would suggest, it is confined to a subset of plants within the metals industry that is towards the end of its industry life cycle.

To achieve this goal, we separate the sample into three different groups of manufacturing plants: the whole manufacturing sector, the metals industry only, and the non-metals industries. Just as before we use OLS and logistic regression models to explore whether each of Marshall's (1890) trinity of agglomeration economies decrease economic performance, whereby each dependent variable is a measure of the plant's economic performance and each independent variable is a measure of Marshall's (1890) agglomeration economies. However, as the size of the sample has been restricted, we use bivariate regression analysis with one dependent variable and one independent variable. By restricting the bivariate regression analysis to only a subset of manufacturing plants within the metals industry, this does limit the ability of the regression results to be representative of the wider population of manufacturing plants within the city-region. Furthermore, as bivariate regression analysis is unable to control simultaneously for other factors that also influence economic performance, this can introduce substantial limitations, such as spurious relationships and omitted variable bias, which need to be taken into consideration (Kennedy, 2003).

Following formal definitions used in the engineering sciences (Pickering, 1978), we classify a manufacturing plant as being within the metals industry if the majority of its material inputs or final products contain either a ferrous or non-ferrous metal (Tweedale, 1995). Using this approach, we find that the majority of manufacturing plants, some $62 \%$, were identified as being within the metals industry, which indicates that we are capturing the contours of the metals agglomeration within the city-region. Examples of manufacturing plants within the metals industry include: metal steel producers, metal bar and tube producers, metal rolling mills, metal drawing mills, first processors of metal, metal ingot manufacturers, metal foundries, metal casters, metal forgers, metal pressing and stamping firms, metal finishing firms, metalworking firms, metal precision engineering firms, and fabricated metal product manufacturers.

In order to illustrate the long-standing presence of the metals industry within the cityregion, we collected data on the ownership history of each manufacturing plant in order to provide a barometer of how the sampled firms represent the contours of the metals industry life cycle. First, the majority of the manufacturing plants within this study operated within the metals industry, and many of these managers explained to us how the metals industry and the local metals agglomeration had evolved over time. Second, our research includes a number of the metal manufacturers that Marshall (1890) studied when he conducted his face-to-face interviews with managers of manufacturing plants within the city-region. Furthermore, approximately $25 \%$ of the manufacturing plants within our study were established before the start of the 20th century, and this study also includes many of the oldest metal producing companies in the world (Tweedale, 1995). Third, this history of local ownership is clearly illustrated by the fact that $51 \%$ of manufacturing plants within our research are owned locally within the city-region, especially within the metals industry. Finally, the stability of the sample is also illustrated by the fact that there was a long history of local ownership within the cityregion with more than half of the manufacturing plants experiencing no ownership change within their company's history. In summary, these findings suggest that although there has been considerable turnover of manufacturing plants, there is a longstanding presence of the metals industry within the city-region. 
As expected, the results from the bivariate regression analysis in Tables 7, 8 and 9 identify that the negative impact of Marshall's (1890) agglomeration economies on economic performance is generally more pronounced for the manufacturing plants within the metals industry. First, the results in Table 7 indicate that highly skilled labour increases both labour costs $(P<0.01)$ and total costs $(P<0.10)$, and this effect is especially apparent within the metals industry rather than the non-metals industries. Second, within Table 8, the $B$ coefficients and level of statistical significance are greater for manufacturing plants within the metals industry, which suggests that the negative impact of local supplier linkages on cost growth $(P<0.05)$ and profit margin $(P<0.05)$ is more pronounced within the metals industry. Finally, Table 9 presents the results for the impact of local knowledge spillovers, which identify that the negative impact of local knowledge spillovers on sales turnover $(P<0.05)$ and profit growth $(P<0.01)$ is more acute within the metals industry rather than the non-metals industries. Further bivariate regression analysis for plants within the metals industry also shows that a local pool of skilled labour reduces the likelihood profitability $(P<0.10)$; local supplier linkages increase total costs $(P<0.10)$, reduce profitability $(P<0.05)$, and lower profits growth $(P<0.05)$; and local knowledge spillovers increase costs growth $(P<0.05)$. In total, within the metals industry, Marshall's $(1890)$ agglomeration economies are found to have 11 significant negative impacts on economic performance, and no beneficial impact whatsoever. It is therefore possible to deduce that the negative impact of Marshall's agglomeration economies is confined primarily to the metals industry, which, importantly, is the polar opposite of the conclusions made by Marshall (1890) when he studied the Sheffield metals industry towards the start of the Agglomeration Life Cycle ( $A L C$ ) Model. In summary, these results clearly illustrate that we are detecting the decline of the metals agglomeration at the end of the Agglomeration Life Cycle ( $A L C$ ) Model, and that whether Marshall's (1890) agglomeration economies generate increasing returns or diminishing returns does indeed depend on time, and especially the evolution of the industry life cycle. Just as Marshall identified that his agglomeration economies were industry specific and represent what we now call localization economies (Hoover, 1937), we too have found that Marshall's (1890) agglomeration economies are industry specific, but are now generating diminishing returns rather than the much cited increasing returns that Marshall (1890) found within the city-region.

\section{Theoretical discussion: 'timing is everything'}

Traditionally, economic geographers argue that agglomeration and geographical proximity can improve firm performance, create increasing returns, generate urban development, and foster regional growth (Krugman, 1991a, 1991b, Arthur, 1994; Baldwin et al., 2003). Many justify this association by invoking Marshall's (1890) agglomeration theory, and his classical example of agglomeration: the industrial districts of the Sheffield metals industry (Krugman, 1991a; Venables, 1999; Fujita et al., 1999; Storper, 1989; Scott, 1999; Amin, 2002; Bathelt et al., 2004; Becattini, 2006). Using multivariate econometric analysis, our empirical results show that each of Marshall's (1890) trinity of agglomeration economies is currently decreasing the economic performance of manufacturing plants within the same city-region where Marshall (1890) first discovered that agglomeration economies create increasing 
Table 7. Metals agglomeration: when a local pool of skilled labour increases labour costs and total costs (bivariate results)

\begin{tabular}{|c|c|c|c|c|c|c|c|c|c|c|c|c|c|}
\hline $\begin{array}{l}\text { OLS model: } \\
\text { labour costs }\end{array}$ & All plant & & Metals & & Non-meta & & $\begin{array}{l}\text { OLS model: } \\
\text { total costs }\end{array}$ & All plant & & Metals & \multicolumn{3}{|c|}{ Non-metals } \\
\hline $\begin{array}{l}\text { Highly skilled } \\
\text { labour }\end{array}$ & $0.11^{* *}$ & $(0.05)$ & $0.25^{* * *}$ & $(0.01)$ & -0.06 & $(0.75)$ & $\begin{array}{l}\text { Highly skilled } \\
\text { labour }\end{array}$ & $0.12^{* *}$ & $(0.02)$ & $0.12^{*}$ & $(0.06)$ & -0.04 & $(0.76)$ \\
\hline (Constant) & $9.50^{* * *}$ & $(0.00)$ & $8.98^{* * *}$ & $(0.00)$ & $10.07^{* * *}$ & $(0.00)$ & (Constant) & $10.81^{* * * *}$ & $(0.00)$ & $10.78^{* * *}$ & $(0.00)$ & $11.49^{* * *}$ & $(0.00)$ \\
\hline$R^{2}$ & 0.03 & & 0.13 & & 0.00 & & $R^{2}$ & 0.06 & & 0.05 & & 0.00 & \\
\hline$n$ & 79 & & 49 & & 30 & & $n$ & 79 & & 49 & & 30 & \\
\hline
\end{tabular}

Notes: Within the metals industry, further bivariate analysis reveals that highly skilled labour also reduces the likelihood of profitability $(P<0.10)$.

*** Significant at the $99 \%$ level; **Significant at the $95 \%$ level; *Significant at the $90 \%$ level (one-tailed tests).

Table 8. Metals agglomeration: when local supplier linkages increase cost growth and decrease profit margins (bivariate results)

\begin{tabular}{|c|c|c|c|c|c|c|c|c|c|}
\hline $\begin{array}{l}\text { Logistic model: } \\
\text { cost growth }\end{array}$ & All plants & & Metals & & Non-metals & $\begin{array}{l}\text { OLS model: } \\
\text { profit margin }\end{array}$ & All plants & Metals & Non-metals \\
\hline $\begin{array}{l}\text { Local supplier } \\
\quad \text { linkage }\left(\mathrm{LSL}_{2}\right)\end{array}$ & $1.03^{* *}$ & $(0.02)$ & $1.82^{* *}$ & $(0.02)$ & $0.89(0.34)$ & $\begin{array}{l}\text { Local supplier } \\
\quad \text { linkage }\left(\mathrm{LSL}_{2}\right)\end{array}$ & $-8.12^{* * *}(0.01)$ & $-11.17^{* *}(0.02)$ & $-6.11^{*}(0.08)$ \\
\hline (Constant) & $-0.87^{* * *}$ & $(0.00)$ & $-1.34^{* * *}$ & $(0.00)$ & $-0.44(0.34)$ & (Constant) & $6.11^{* * *}(0.01)$ & $9.33^{* *}(0.02)$ & $3.29 *(0.09)$ \\
\hline Cox and Snell $R^{2}$ & 0.05 & & 0.12 & & 0.03 & & & & \\
\hline Nagelkerke $R^{2}$ & 0.07 & & 0.17 & & 0.04 & $R^{2}$ & 0.07 & 0.10 & 0.07 \\
\hline$n$ & 79 & & 49 & & 30 & $n$ & 79 & 49 & 30 \\
\hline
\end{tabular}

Notes: Within the metals industry, local supplier linkages $\left(\mathrm{LSL}_{2}\right)$ also increase total costs $(P<0.10)$, reduce profitability $(P<0.05)$, and lower profit growth $(P<0.05)$.

${ }^{* * *}$ Significant at the $99 \%$ level; ${ }^{* *}$ Significant at the $95 \%$ level; ${ }^{*}$ Significant at the $90 \%$ level (one-tailed tests).

Table 9. Metals agglomeration: when local knowledge spillovers decrease sales turnover and decrease profit growth (bivariate results)

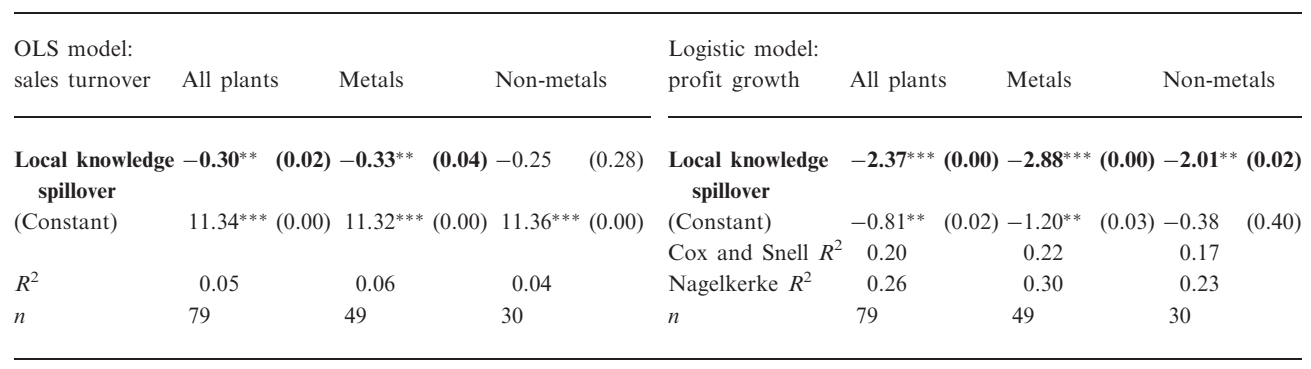

Notes: Within the metals industry, further bivariate analysis identifies that local knowledge spillovers also increase the likelihood of cost growth $(P<0.05)$.

*** Significant at the $99 \%$ level; **Significant at the $95 \%$ level; *Significant at the $90 \%$ level (one-tailed tests). 
returns. Whilst bearing in mind the limitations of our empirical analysis and the overrepresentation of larger manufacturers, it appears that the manufacturing plants that rely upon a local pool of skilled labour experience higher labour costs and higher total costs, maintaining local supplier linkages causes cost growth and lower profit margins, and receiving local knowledge spillovers creates lower sales turnover and lower profit growth. Crucially, we also demonstrate that the negative impact of Marshall's (1890) agglomeration economies on economic performance is confined primarily to the metals industry that is towards the end of its industry life cycle, which importantly, is the opposite of the conclusions made by Marshall (1890) when he studied the same agglomeration at the start of the industry life cycle.

Somewhat ironically, whilst many economic geographers continue to use Marshall's (1890) agglomeration theory to argue that agglomeration generates increasing returns (Porter, 1990; Krugman, 1991a), the original agglomeration wherein Marshall (1890) discovered his theory has caused the city and the surrounding region to evolve into one of the poorest regions in Europe (European Commission, 2005). Furthermore, it is rarely acknowledged within the economic geography literature that it was during the early stages of the industry life cycle that Marshall (1890) interviewed firms within the city-region and concluded that these firms were experiencing increasing returns from a trinity of agglomeration economies. However, when we interviewed similar manufacturing plants from the same city-region, but during the later stages of the industry life cycle, we find that Marshall's (1890) agglomeration economies are creating diminishing returns instead. For example, using the population of the city of Sheffield over the past 200 years as a general approximation of the evolution of the Agglomeration Life Cycle (ALC) Model, it is clear to see that Marshall's (1890) agglomeration theory only applied to a particular time period in the life cycle of the metals industry (Figure 3).

Over a century ago, Marshall (1890) warned explicitly that agglomeration was a double-edged sword for economic development. A close inspection of Marshall's (1890, 273) classical texts reveals that he also argued that agglomeration can generate substantial diminishing returns, which could culminate in 'extreme depressions' if an agglomeration is dependent on one industry for its economic development (Martin, 2006). This agglomeration risk is rarely cited or acknowledged, which is surprising considering that our results show that this is precisely what eventually happened to the city-region where Marshall (1890) argued that agglomeration generated increasing returns. As Marshall (1890) goes on to argue, one of the ways to avoid this agglomeration risk is for the city-region to contain a heterogeneous industrial base that incorporates a variety of different industries and agglomerations. In the words of Marshall $(1890,273)$, 'this evil is in a great measure avoided by those large towns or large industrial districts in which several distinct industries are strongly developed. If one of them fails for a time, the others are likely to support it indirectly...' In other words, for city-regions with a heterogeneous industrial base and a diverse number of industries at different stages of their life cycles, the decline of one industry can be offset or mitigated by the growth of other industries. Although many economic geographers associate Marshall (1890) with the advantages of regional specialization (i.e. the socalled Marshall Arrow Romer perspective), it is worth noting that he also highlighted the importance of heterogeneity, variety and diversity to economic growth (i.e. the Jacobs perspective) (Jacobs, 1969; Glaeser et al., 1992). For example, Marshall (1890, 272) argues 'The advantages of variety of employment are combined with those of localized industries in some of our manufacturing towns, and this is a chief cause of 


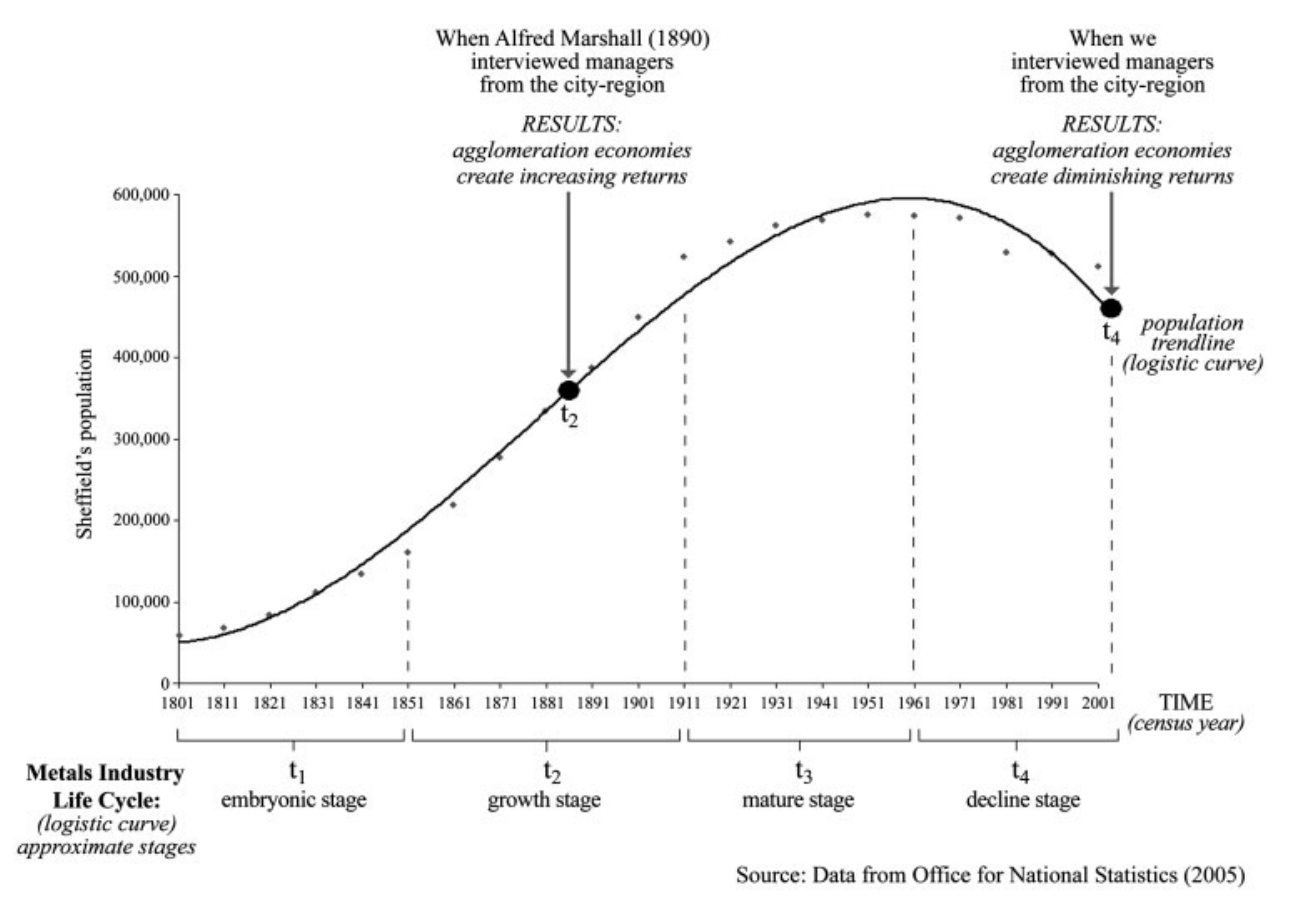

Figure 3. The evolution of Marshall's (1890) agglomeration economies and the industry life cycle.

their continued growth.' We call this the heterogeneity paradox. To resolve it, we suggest that the importance of regional specialization and diversity to development varies depending upon timing and especially the evolution of the industry life cycle (Menzel and Fornahl, 2009; Neffke et al., 2010; Wal and Boschma, 2010).

\section{Conclusions and future research directions}

Since Darwin's (1859) classic publication On the Origin of Species and Marshall's (1898, 43-47) declaration that 'the Mecca of the economist is economic biology', there has been a growing interest within economics and the wider social sciences in evolutionary models, theories, concepts, perspectives, metaphors, and methodologies (Schumpeter, 1942; Nelson and Winter, 1982; Hodgson, 1993). Recently, Boschma and Martin (2007) have outlined an evolving theoretical framework for a third approach to economic geography that complements the neo-classical and the institutional approaches, whilst simultaneously drawing upon research from evolutionary economics and biology (Boschma and Lambooy, 1999; Boschma and Frenken, 2006; Boschma and Martin, 2007; Essletzbichler and Rigby, 2007). According to Boschma and Frenken (2006), Evolutionary Economic Geography (EEG) '... aims to improve our theoretical and empirical understanding of the economy as an evolutionary process that unfolds in space and time'. As Boschma and Frenken (2006) point out, evolutionary economic geography explains regional development similarities and differences from the micro-histories of 
individual firms and industries that operate within territorial contexts (Martin and Sunley, 2006; Frenken and Boschma, 2007; Frenken, 2007). Put simply, 'history matters' (David, 1985). Building upon this evolutionary turn within the economic geography literature, we outline an Evolutionary Agglomeration Theory (EAT) that argues that the industry life cycle plays a pivotal role in explaining the evolution of firms, industries, agglomerations, networks, supply chains, increasing returns, diminishing returns, cities and regions. Such an approach views the growth and decline of the industry life cycle as a important determinant of the rise and fall of different agglomerations and city-regions through time and across geographical space (Boschma and Frenken, 2006; Boschma and Wenting, 2006). This approach enhances our understanding of the life cycle of agglomerations from their birth and growth to their eventual maturity and decline, and emphasizes that the importance of regional specialization and diversity to development varies throughout the industry life cycle (Wal and Boschma, 2010; Menzel and Fornahl 2009; Neffke et al., 2010). By extension, we suggest that that similarities and differences between territories can be understood in the context of long term evolutionary processes and structural change (Boschma and Frenken, 2006), and that diverging regional development trajectories represent the spatial outcome of city-regions that have become locked into industries that are at different stages of the industry life cycle.

According to Evolutionary Agglomeration Theory (EAT), Marshall's (1890) agglomeration economies evolve over time and across geographical space in a manner that represents an Agglomeration Life Cycle ( $A L C$ ) Model. Specifically, we have argued that Marshall's (1890) agglomeration economies create greater economic performance and increasing returns during the early stages of the industry life cycle, but decreasing economic performance and diminishing returns during the later stages of the industry life cycle. We have investigated this theory by examining empirically whether Marshall's (1890) agglomeration economies decrease the economic performance of manufacturing plants during the later stages of the industry life cycle. To evaluate our research hypotheses, we returned to where it all began: the original agglomeration wherein Marshall (1890) discovered that manufacturing plants experience increasing returns from a trinity of agglomeration economies. Whilst acknowledging the over-representation of larger manufacturing plants and the limitations of our empirical analysis, the econometric results from our multivariate regression models identified that Marshall's (1890) trinity of agglomeration economies are currently decreasing the economic performance of manufacturing plants within the city-region. In short, Marshall's (1890) agglomeration economies have a negative impact on the costs, turnover, and profitability of the manufacturing plants, including measures such as profit margin, which is one of the most important measures of economic performance. Overall, none of Marshall's (1890) agglomeration economies are found to have any statistically significant beneficial impact on economic performance whatsoever. Importantly, we also identify that the negative impact of Marshallian agglomeration economies on economic performance was more pronounced within the metals industry, which as theory suggests, is in accordance with the evolution of the Agglomeration Life Cycle ( $A L C$ ) Model.

Although our study is limited to the evolution of the agglomeration where Marshall (1890) first discovered that agglomeration economies create increasing returns, our findings raise a number of important avenues for future research to explore. First, future research is required to examine whether Evolutionary Agglomeration Theory (EAT) and the Agglomeration Life Cycle (ALC) Model apply to the development of 
different firms, industries, agglomerations, networks, supply chains, and city-regions. Broadly speaking, this could explain why many of the industries, agglomerations, networks, and city-regions that evolved from the Industrial Revolution experienced rapid growth and development during the 19th century, but eventually matured and declined throughout the 20th century. Second, greater emphasis could be given to evolutionary processes within the economic geography literature, especially with regards to the evolution of agglomerations, networks and supply chains over time and geographical space, and how managers can successfully adapt their practices, routines, strategies, and dynamic capabilities throughout the life cycle (e.g. supply chain evolution). Furthermore, although a large number of theories and models do focus on evolutionary processes at the beginning of the industry life cycle, comparatively few extend their analysis to the rest of the life cycle, which accounts for the majority of firms within a region's economy (i.e. the timing bias). Third, further research is required to investigate whether diverging regional development trajectories, such as the NorthSouth divide within Great Britain or the difference between the Rust Belt and Sun Belt within the USA, represent the spatial outcome of city-regions that are locked in to industries at different stages of the industry life cycle. Four, future research could explore what is likely to happen when the new industries and growth agglomerations found within the South East of England and Silicon Valley within the USA begin to mature and potentially decline during the later stages of the industry life cycle. Finally, when designing future theoretical models, policies, managerial recommendations, and business strategies, economic geographers need to incorporate into their analysis the fact that Marshall's (1890) agglomeration economies can generate both increasing returns and diminishing returns for economic development, and that this depends to a large extent on the evolution of the industry life cycle. In the words of Hekman (1979): 'regions don't grow old; products do.'

\section{Acknowledgements}

We are grateful to two anonymous referees for their constructive comments on the earlier version of this article. We gratefully acknowledge the financial support given to this research by the Economic and Social Research Council (ESRC), and the European Commission (EC). Special thanks go to the academics who commented on earlier versions of this article, colleagues at the University of Sheffield, Queen's University Belfast, and the European Commission. We would also like to thank Professor Harvey Armstrong from the University of Sheffield, and Costas Georgiou (Research and Evaluation Manager) and Tony Newson (Programme Chief Executive) from the European Commission (EC) [Objective 1 Programme Directorate].

\section{Funding}

This work was supported by research grants from the Economic and Social Research Council (ESRC) [research grant number: PTA033200200056], the European Commission (EC) [Objective 1 Programme Directorate], and a Collaborative Award in Science and Engineering [CASE Award]. The usual disclaimers apply.

\section{References}

Abernathy, W.J., Utterback, J.M. (1978) Patterns of innovation in industry. Technology Review, 80: 40-47.

Agarwal, R. (1997) Survival of firms over the product life cycle. Southern Economic Journal, 63: 571-584. 
Agarwal, R., Audretsch, D. (2001) Does entry size matter? The impact of the life cycle and technology on firm survival. Journal of Industrial Economics, 49: 21-43.

Agarwal, R., Gort, M. (1996) The evolution of markets and entry, exit and survival of firms. Review of Economics and Statistics, 78: 489-498.

Agarwal, R., Gort, M. (2002) Firm and product life cycles and firm survival. American Economic Review, 92: 184-190.

Alonso, W. (1964) Location and Land Use: Toward A General Theory of Land Rent. Cambridge: Harvard University.

Amin, A. (2002) Industrial districts. In E.S. Sheppard (ed.) A Companion to Economic Geography, pp. 149-169. London: Blackwell Publishing.

Anderson, P., Tushman, M.L. (1990) Technological discontinuities and dominant designs: Cyclical model of technological change. Administrative Science Quarterly, 35: 604-633.

Arrow, K. (1962) The economic implications of learning by doing. Review of Economic Studies, 29: $155-173$.

Arthur, W.B. (1994) Increasing Returns and Path Dependence in the Economy. Ann Arbor: Michigan Press.

Audretsch, D., Feldman, M. (1996) Innovative clusters and the industry life cycle. Review of Industrial Organization, 11: 253-273.

Axelrod, R., Hamilton, W.D. (1981) The evolution of cooperation. Science, 211: 1390-1396.

Bair, J., Gereffi, G. (2001) Local clusters in global chains: the causes and consequences of export dynamism in Torreon's blue jeans industry. World Development, 29: 1885-1903.

Baldwin, R.E., Forslid, R., Martin, P., Ottaviano, G., Robert-Nicoud, F. (2003) Economic Geography and Public Policy. Princeton, NJ: Princeton University Press.

Banerjee, A.V. (1992) A simple model of herd behavior. Quarterly Journal of Economics, 107: 797-817.

Barnes, T. (1996) Logics of Dislocation: Models, Metaphors and Meanings of Economic Space. London: Guilford Press.

Bathelt, H., Malmberg, A., Maskell, P. (2004) Clusters and knowledge: local buzz, global pipelines and the process of knowledge creation. Progress in Human Geography, 28: 31-56.

Becattini, G. (2006) The industrial district and development economics. In T. Raffaelli, G. Becattini, M. Dardi (eds) The Elgar Companion to Alfred Marshall, pp. 664-672. Cheltenham: Edward Elgar.

Booth, D. E. (1986) Long waves and uneven regional growth. Southern Economic Journal, 53: 448-460.

Boschma, R.A., Lambooy, J.G. (1999) Evolutionary economics and economic geography. Journal of Evolutionary Economics, 9: 411-429.

Boschma, R.A., Frenken, K. (2006) Why is economic geography not an evolutionary science? Journal of Economic Geography, 6: 273-302.

Boschma, R., Frenken, K. (2009) Some notes on institutions in evolutionary economic geography. Economic Geography, 85: 151-158.

Boschma, R., Martin, R. (2007) Constructing an evolutionary economic geography. Journal of Economic Geography, 7: 537-548.

Boschma, R.A., Wenting, R. (2007) The spatial evolution of the British automobile industry: does location matter? Industrial and Corporate Change, 16: 213-238.

Boschma, R.A., Eriksson, R., Lindgren, U. (2009) How does labour mobility affect the performance of plants? The importance of relatedness and geographical proximity. Journal of Economic Geography, 9: 169-190.

Breschi, S., Lissoni, F. (2001) Knowledge spillovers and local innovation systems: a critical survey. Industrial and Corporate Change, 10: 975-1005.

Brezis, E.S., Krugman, P.R. (1997) Technology and the life cycle of cities. Journal of Economic Growth, 2: 369-383.

Camagni, R. (1991) Local 'milieu', uncertainty and innovation networks: towards a new dynamic theory of economic space. In R. Camagni (ed.) Innovation Networks: Spatial Perspectives. London: Belhaven.

Campbell, N.A., Reece, J.B., Urry, L.A., Cain, M.L., Wasserman, S.A., Minorsky, P.V., Jackson, R.B. (2008) Biology, 8th edn. London: Persons International.

Checkland, S.G. (1976) The Upas Tree: Glasgow 1875-1975. Glasgow: Glasgow University Press. 
Chinitz, B. (1961) Contrasts in agglomeration. American Economic Review, 51: 279-89.

Companies House, (2005) The Official UK Government Register of UK Companies. London: Companies House Executive Agency. Available online at: http://www.companieshouse.gov.uk [Accessed 10 October 2009].

Cooke, P. (1990) Back to the Future: Modernity, Postmodernity and Locality. London: Routledge.

Crone, M., Roper, S. (2001) Local learning from multinational plants: knowledge transfers in the supply chain. Regional Studies, 35: 535-548.

Crone, M., Watts, H.D. (2003) The determinants of regional sourcing by multinational manufacturing firms: Evidence from Yorkshire and Humberside. European Planning Studies, 11: 717-737.

Darwin, C. (1859) The Origin of Species by Means of Natural Selection. New York: Washington Square Press.

David, P.A. (1985) Clio and the economics of QWERTY. American Economic Review, 75: 332-337.

Deily, M.E. (1991) Exit strategies and plant-closing decisions. RAND Journal of Economics, 22: 250-263.

Dicken, P. (2003) Global shift. London: Sage Publications.

Dosi, G., Nelson, R.R. (1994) An introduction to evolutionary theories in economics. Journal of Evolutionary Economics, 4: 153-172.

Dunne, T., Roberts, M.J., Samuelson, L. (1988) Patterns of firm entry and exit in U.S. manufacturing industries. RAND Journal of Economics, 19: 495-515.

Dunning, J.H. (2000) Regions, Globalization, and the Knowledge-based Economy. Oxford: Oxford Press.

Duranton, G., Overman, H.G. (2005) Testing for localization using micro-geographic data. Review of Economic Studies, 72: 1077-1106.

Duranton, G., Puga, D. (2001) Nursery cities: Urban diversity, process innovation, and the life cycle of products. American Economic Review, 91: 1454-1477.

Ehrlich, P.R., Raven, P.H. (1964) Butterflies and plants: a study in coevolution. Evolution, 18: 586-608.

Essletzbichler, J., Rigby, D.L. (2007) Exploring evolutionary economic geographies. Journal of Economic Geography, 7: 549-571.

European Commission. (2005) South Yorkshire Objective 1 Programme Directorate. Rotherham: European Commission. Available online at: http://www.goyh.gov.uk/goyh/eurofund/ol/ [Accessed 10 October 2009].

Frenken, K. (ed.) (2007) Applied Evolutionary Economics and Economic Geography. Cheltenham: Edward Elgar.

Frenken, K., Boschma, R.A. (2007) A theoretical framework for evolutionary economic geography: industrial dynamics and urban growth as a branching process. Journal of Economic Geography, 7: 635-649.

Futuyma, D.J. (1998) Evolutionary Biology, third edition. New York: Sinauer Publishers.

Fujita, M., Krugman, P., Venables, A. (1999) The Spatial Economy: Cities, Regions, and International Trade. London: MIT Press.

Gertler, M.S. (1995) "Being there": proximity, organization, and culture in the development and adoption of advanced manufacturing technologies. Economic Geography, 71: 1-26.

Glaeser, E.L. (2005) Reinventing Boston: 1630-2003. Journal of Economic Geography, 5: 119-153.

Glaeser, E.L., Kallal, H.D., Scheinkman, J.A., Shleifer, A. (1992) Growth in cities. Journal of Political Economy, 100: 1126-1152.

Grabher, G. (1993) The weakness of strong ties: the 'lock-in' of regional development in the Ruhr area. In G. Grabher (ed.) The Embedded Firm: On the Socio-economics of Industrial Networks, pp. 255-277. London: Routledge.

Grabher, G. (2009) Yet another turn? The evolutionary project in economic geography. Economic Geography, 85: 119-127.

Granovetter, M. (1985) Economic action and social structure: the problem of embeddedness. American Journal of Sociology, 91: 481-510.

Greene, W.H. (2008) Econometric Analysis. London: Pearson Prentice Hall.

Greenstein, S.M., Wade, J.B. (1998) The product life cycle in the commercial mainframe computer market 1968-1982. RAND Journal of Economics, 29: 772-789. 
Griliches, Z. (1992) The search for R\&D spillovers. Scandinavian Journal of Economics, 94: 29-47.

Gould, S.J., Eldredge, N. (1993) Punctuated equilibrium comes of age. Nature, 366: 223-227.

Groenewegen, A. (1995) A Soaring Eagle: Alfred Marshall 1842-1924. Aldershot: Edward Elgar.

Gujarati, D.N. (2005) Essentials of Econometrics. London: McGraw-Hill.

Hägerstrand, T. (1967) Innovation Diffusion as a Spatial Process. Chicago: Chicago University Press.

Hanski, I. (1998) Metapopulation dynamics. Nature, 396: 41-49.

Harrison, B. (1992) Industrial districts: old wine in new bottles? Regional Studies, 26: $469-483$.

Hayes, R. H., Wheelwright, S.C. (1979) Link manufacturing process and product life cycles. Harvard Business Review, 57: 133-140.

Hayek, F.A. (1945) The use of knowledge in society. American Economic Review, 35: 519-530.

Hekman, J.S. (1979) Regions Don't Grow Old; Products Do. New York: New York Times.

Henderson, J., Dicken, P., Hess, M., Coe, N., Yeung, H.W.C. (2002) Global production networks and the analysis of economic development. Review of International Political Economy, 9: 436-464.

Hewitt-Dundas, N., O’Callaghan, B., Crone, M., Murray, J., Roper, S. (2005) Selling global, buying local? What determines the sourcing patterns of multinational plants in Ireland? Regional Studies, 39: 225-239.

Hey, D. (2005) The South Yorkshire steel industry and the Industrial Revolution. Northern History, 42: 91-96.

Hirschman, A. (1958) The Strategy of Economic Development. New Haven: Yale University Press.

Hodgson, G.M. (1993) Economics and Evolution. Cambridge: Polity Press.

Holland, J.H. (1992) Adaptation in Natural and Artificial Systems. Cambridge: MIT Press.

Hoover, E.M. (1937) Location Theory and The Shoe and Leather Industries. Cambridge: Harvard University Press.

Huston, M., Smith, T. (1987) Plant succession: life history and competition. American Naturalist, 130: $168-198$.

Jacobs, J. (1969) The Economy of Cities. New York: Random House.

Jaffe, A.B., Trajtenberg, M., Henderson, R. (1993) Geographic localization of knowledge spillovers. Quarterly Journal of Economics, 108: 577-598.

Johansson, B., Quigley, J.M. (2004) Agglomeration and networks in spatial economies. Papers in Regional Science, 83: 165-176.

Jovanovic, B., Lach, S. (1989) Entry, exit, and diffusion with learning by doing. American Economic Review, 79: 690-699.

Jovanovic, B., MacDonald, G.M. (1994) The life cycle of a competitive industry. Journal of Political Economy, 102: 322-347.

Kennedy, P. (2003) A Guide to Econometrics. Oxford: Blackwell Publishing.

Klepper, S. (1996) Entry, exit, growth, and innovation over the product life cycle. American Economic Review, 86: 562-583.

Klepper, S. (1997) Industry life cycles. Industrial and Corporate Change, 6: 145-182.

Klepper, S. (2007) Disagreements, spinoffs, and the evolution of Detroit as the capital of the U.S. automobile industry. Management Science, 53: 616-631.

Klepper, S., Graddy, E. (1990) The evolution of new industries and the determinants of market structure. RAND Journal of Economics, 21: 27-44.

Klepper, S., Miller, J.H. (1995) Entry, exit, and shakeouts in the United States in new manufactured products. International Journal of Industrial Organization, 13: 567-591.

Klepper, S., Sleeper, S. (2005) Entry by spinoffs. Management Science, 51: 1291-1306.

Koser, K., Salt, J. (1997) The geography of highly skilled international migration. International Journal of Population Geography, 3: 285-303.

Krugman, P. (1991a) Geography and Trade. Cambridge: MIT Press.

Krugman, P. (1991b) Increasing returns and economic geography. Journal of Political Economy, 99: 483-99.

Krugman, P., Obstfeld, M. (2009) International Economics: Theory and Policy, 8th edn. Reading: Pearson.

Lee, R. (2000) Industrial districts. In R. Johnston, D. Gregory, G. Pratt, M. Watts (eds) Dictionary of Human Geography, pp. 380-382. London: Blackwell. 
Lever, W.F. (1972) Industrial movement, spatial association and functional linkages. Regional Studies, 6: 371-384.

Lieberman, M.B., Montgomery, D. (1988) First-mover advantages. Strategic Management Journal, 9: 41-58.

Lieberman, M.B. (1990) Exit from declining industries: "shakeout" or "stakeout"? RAND Journal of Economics, 21: 538-554.

Lippman, S.A., Rumelt, R.P. (1982) Uncertain imitability: an analysis of interfirm differences in efficiency under competition. Bell Journal of Economics, 13: 418-438.

Loasby, B. J. (2006) Industrial organization. In T. Raffaelli, G. Becattini, M. Dardi (eds) The Elgar Companion to Alfred Marshall, pp. 371-379. Cheltenham: Edward Elgar.

Londregan, J. (1990) Exit and entry over the industry life cycle. RAND Journal of Economics, 21: 446-458.

Malmberg, A., Malmberg, B., Lundequist, P. (2000) Agglomeration and firm performance: economies of scale, localization, and urbanization among Swedish export firms. Environment and Planning A, 32: 305-321.

Mansfield, E. (1961) Technical change and the rate of imitation. Econometrica, 29: 741-766.

Markusen, A. (1996) Sticky places in slippery space: a typology of industrial districts. Economic Geography, 72: 293-313.

Marshall, A. (1890) Principles of Economics. London: Macmillan.

Marshall, A. (1898) Distribution and exchange. Economic Journal, 8: 37-59.

Marshall, A. (1919) Industry and Trade. London: MacMillan.

Martin, R. (2006) The localization of industry. In T. Raffaelli, G. Becattini, M. Dardi (eds) The Elgar Companion to Alfred Marshall, pp. 393-401. Cheltenham: Edward Elgar.

Martin, R., Sunley, P. (1996) Paul Krugman's geographical economics and its implications for regional development theory: A critical assessment. Economic Geography, 72: 259-292.

Martin, R., Sunley, P. (2003) Deconstructing clusters: chaotic concept or policy panacea? Journal of Economic Geography, 3: 5-35.

Martin, R., Sunley, P. (2006) Path dependence and regional economic evolution. Journal of Economic Geography, 6: 395-437.

Maskell, P., Malmberg, A. (2007) Myopia, knowledge development and cluster evolution. Journal of Economic Geography, 7: 603-618.

Matouschek, N., Robert-Nicoud, F. (2005) The role of human capital investments in the location decision of firms. Regional Science and Urban Economics, 35: 570-583.

Menzel, M.P., Fornahl, D. (2009) Cluster life cycles - dimensions and rationales of cluster evolution. Industrial and Corporate Change, 19: 205-238.

Neffke, F., Henning, M.S., Boschma, R.A., Lundquist, K.J., Olander, L.O. (2010) The dynamics of agglomeration externalities along the life cycle of industries. Regional Studies, (forthcoming).

Nelson, R.R., Winter, S.G. (1982) An Evolutionary Theory of Economic Change. Cambridge: Harvard Press.

NOMIS, (2005) Official Labor Market Statistics for South Yorkshire. Durham: NOMIS. Available online at: http://www.nomisweb.co.uk/reports/lmp/la/1967128608/report.aspx? town $=$ South $\% 20$ Yorkshire [Accessed 10 October 2009].

Norton, R.D., Rees, J. (1979) The product cycle and the spatial decentralization of American manufacturing. Regional Studies, 13: 141-151.

Office for National Statistics, (2005) Sheffield Census Data. London: ONS. Available online at: http://www.statistics.gov.uk/.

PA1003, (2005) VAT Based Enterprises by Unitary Authorities and Districts Within Counties by Broad Industry Group. London: Office of National Statistics.

Penrose, E.T. (1952) Biological analogies in the theory of the firm. American Economic Review, 42: 804-819.

Phelps, N.A. (1992) External economies, agglomeration and flexible accumulation. Transactions of the Institute of British Geographers, 17: 35-46.

Phelps, N., Ozawa, T. (2003) Contrasts in agglomeration: proto-industrial and post-industrial forms compared. Progress in Human Geography, 27: 583-604.

Pickering, F.B. (1978) Physical Metallurgy and The Design of Steels. London: Applied Science Publishers. 
Porter, M. (1990) The Competitive Advantage of Nations. London: Macmillan.

Potter, J., Moore, B., Spires, R. (2003) Foreign manufacturing investment in the UK and the upgrading of supplier practices. Regional Studies, 37: 41-60.

Press, K. (2006) A Life Cycle for Clusters? The Dynamics of Agglomeration, Change and Adaptation. Heidelberg: Physica-Verlag.

Pyke, F.G., Becattini, G., Sengenberger, W. (1990) Industrial Districts and Interfirm Cooperation in Italy. Geneva: Inter-national Institute for Labour Studies.

Raffaelli, T., Becattini, G., Dardi, M. (eds) (2006) The Elgar Companion to Alfred Marshall. Cheltenham: Edward Elgar.

Ricklefs, R.E., Miller, G. (2000) Ecology, fourth edition. New York: Freeman and Co.

Ridley, M. (2004) Evolution, third edition. Oxford: Blackwell Publishing.

Rigby, D., Essletzbichler, J. (1997) Evolution, process variety, and regional trajectories of technological change in U.S. manufacturing. Economic Geography, 73: 269-284.

Robson, P.J.A., Bennett, R.J. (2000) The use and impact of business advice by SMEs in Britain. Applied Economics, 32: 1675-1688.

Romer, P. (1986) Increasing returns and long-run growth. Journal of Political Economy, 94: $1002-1037$.

Rosenthal, S.S., Strange, W.C. (2004) Evidence on the nature and sources of agglomeration economies. In J.V. Henderson, J.F. Thisse (eds) Handbook of Urban and Regional Economics, . vol. 4. Amsterdam: Elsevier Science Publishers.

Sabel, C., Zeitlin, J. (1985) Historical alternatives to mass production: politics, markets and technology in nineteenth century industrialization. Past and Present: A Journal of Historical Studies, 108: 133-176.

Sadler, D. (2004) Cluster evolution, the transformation of old industrial regions and the steel industry supply chain in North East England. Regional Studies, 38: 55-66.

Saxenian, A.L. (1994) Regional Advantage: Culture and Competition in Silicon Valley and Route 128. Cambridge, MA: Harvard University Press.

Schumpeter, J.A. (1941) Alfred Marshall's Principles: a semi-centennial appraisal. American Economic Review, 51: 85-98.

Schumpeter, J.A. (1942) Capitalism, Socialism, and Democracy. New York: Harper.

Scott, A.J. (1983) Industrial organization and the logic of intra-metropolitan location: I. theoretical considerations. Economic Geography, 59: 233-250.

Scott, A.J. (1999) The geographical foundations of industrial performance. In A. D. Chandler, P. Hagstrom, O. Solvell (eds) The Dynamic Firm: The Role of Technology, Strategy, Organization, and Regions, pp. 384-402. London: Oxford University Press.

Segerstrom, P.S., Anant, T.C.A., Dinopoulos, E. (1990) A Schumpeterian model of the product life cycle. American Economic Review, 80: 1077-1091.

Simmie, J. (1997) The origins and characteristics of innovation in highly innovative areas. In J. Simmie (ed.) Innovation, Networks and Learning Regions?, pp. 11-30. London: Routledge.

Slatkin, M. (1987) Gene flow and the geographic structure of natural populations. Science, 236: 787-792.

Standard Industrial Classification, (2003) Standard Industrial Classification of activities. London: ONS. Available online at: http://www.statistics.gov.uk/methods_quality/sic/ downloads/uk_sic_vol1(2003).pdf [Accessed 10 October 2009].

Storper, M. (1985) Disequilibrium and dynamics in metropolitan economic development in the third world: Reply to Townroe and Hamer. Regional Studies, 19: 51-57.

Storper, M. (1989) The transition to flexible specialization in the US film industry: external economies the division of labor, and the crossing of industrial divides. Cambridge Journal of Economics, 13: 273-305.

Storper, M., Venables, A.J. (2004) Buzz: face-to-face contact and the urban economy. Journal of Economic Geography, 4: 351-370.

Suárez, F.F., Utterback, J.M. (1995) Dominant designs and the survival of firms. Strategic Management Journal, 16: 415-430.

Teece, D.J., Pisano, G., Shuen, A. (1997) Dynamic capabilities and strategic management. Strategic Management Journal, 18: 509-533.

Thomas, B. (1991) Alfred Marshall on economic biology. Review of Political Economy, 3: 1-14. 
Tweedale, G. (1995) Steel City: Entrepreneurship, Strategy and Technology in Sheffield. Oxford: Claredon Press.

Utterback, J.M., Abernathy, J.W. (1975) A Dynamic Model of Process and Product Innovation. London: Pergamon Press.

Veblen, T. (1898) Why is economics not an evolutionary science? Quarterly Journal of Economics, 12: 373-97.

Venables, A.J. (1999) The international division of industries: clustering and comparative advantage in a multi-industry model. Scandinavian Journal of Economics, 101: 495-513.

Vernon, R. (1966) International investment and international trade in the product cycle. Quarterly Journal of Economics, 80: 190-207.

Von Hippel, E. (1998) Economics of product development by users: the impact of "sticky" local information. Management Science, 44: 629-644.

Von Thünen, J.H. (1826) Der isolierte staaat in beziehung auf landtschaft und nationalokonomie. English translation by Wartenburg, C. M. Von Thünen's isolated state. Oxford: Pergamon Press.

Ter Wal, L.J., Boschma, R.A. (2010) Co-evolution of firms, industries and networks in space. Regional Studies, (forthcoming).

Watts, H.D. (1981) The Branch Plant Economy. London: Longmans.

Watts, H.D. (1991) Plant closures, multilocational firms, and the urban economy: Sheffield, United Kingdom. Environment and Planning A, 23: 37-58.

Watts, H.D., Wood, A.M., Wardle, P. (2003) Making friends or making things? Interfirm transactions in the Sheffield metal-working cluster. Urban Studies, 40: 615-630.

Williamson, O.E. (1975) Markets and Hierarchies, Analysis and Antitrust Implications: A Study in the Economics of Internal Organization. New York: Free Press.

Winter, S.G., Szulanski, G. (2001) Replication as strategy. Organization Science, 12: 730-743.

Womack, J.P., Jones, D.T., Roos, D. (1990) The Machine that Changed the World. New York: Harper.

Young, A. A. (1928) Increasing returns and economic progress. Economic Journal, 38: 527-542.

Zander, U., Kogut, B. (1995) Knowledge and the speed of the transfer and imitation of organizational capabilities: an empirical test. Organization Science, 6: 76-92.

Zucker, L.G., Darby, M.R. (2006) Movement of star scientists and engineers and high-tech firm entry. National Bureau of Economic Research, Working Paper W12172. 
Appendix. Descriptive analysis

Variable

Economic performance

Labour costs

Total costs

Cost growth

Sales turnover

Turnover growth

Profitability

Profit margin

Profit growth

\section{Agglomeration economies}

Highly skilled labour

Local supplier linkage

Local knowledge spillover

\section{Control variables}

Plant size

Plant age

Competition

Export intensity

Patent innovation

Multinational
Description

Details
Labour costs per employee (log)

Total costs per employee (log)

Total costs increased over past 3 years

Sales turnover per employee $(\log )$

Sales turnover increased over past 3 years

Whether plant is financially profitable

Pre-tax profit margin (\%) of the plant

Profits increased over past 3 years

Percent of employees trained at university degree level (or to industry's equivalent standard) such as formally qualified engineers, researchers,

technologists or scientists (log)

Sourced from a local key supplier within the city-region that accounts for five percent or more of plant expenditure on materials and components

(i.e. $\mathrm{LSL}_{2}$ )

Received knowledge from a local organization located within the region's manufacturing industry within the past 3 years (e.g. from a local customer, material input supplier, machinery, equipment or tool supplier, service supplier, or other local manufacturing plants)

Number of employees on payroll register at the site $(\log )$

Years since company was first established $(\log )$

Number of competitors in main market $(\log )$

Percentage of sales turnover from exports (outside UK)

Developed a patented innovation in the past 3 years

Plant owned by a multinational enterprise

$$
\begin{aligned}
& \text { Mean }=9.90 \quad \text { s.d. }=0.52 \\
& \text { Mean }=11.26 \quad \text { s.d. }=0.44 \\
& \text { Yes }=29 \% \quad \text { No }=71 \% \\
& \text { Mean }=11.24 \quad \text { s.d. }=0.61 \\
& \text { Yes }=53 \% \quad \text { No }=47 \% \\
& \text { Yes }=75 \% \quad \text { No }=25 \% \\
& \text { Mean }=3 \% \quad \text { s.d. }=15 \% \\
& \text { Yes }=44 \% \quad \text { No }=56 \% \\
& \text { Mean }=3.65 \quad \text { s.d. }=0.88 \\
& \text { Yes }=43 \% \quad \text { No }=57 \% \\
& \text { Yes }=32 \% \quad \text { No }=68 \% \\
& \text { Mean }=5.04 \quad \text { s.d. }=0.89 \\
& \text { Mean }=3.47 \quad \text { s.d. }=1.32 \\
& \text { Mean }=2.07 \quad \text { s.d. }=1.36 \\
& \text { Mean }=31 \% \quad \text { s.d. }=28 \% \\
& \text { Yes }=35 \% \quad \text { No }=65 \% \\
& \text { Yes }=48 \% \quad \text { No }=52 \%
\end{aligned}
$$

